Collection: IUFRO RG 7.01 (2010) - Antalya (Turkey)

Adaptation of Forest Ecosystems to Air Pollution and Climate Change

Guest Editors: Elena Paoletti, Yusuf Serengil

\section{Long-term monitoring of air pollution effects on selected forest ecosystems in the Bucegi-Piatra Craiului and Retezat Mountains, southern Carpathians (Romania)}

\author{
Badea $O^{(1)}$, Neagu $S^{(1-8)}$, Bytnerowicz $A^{(7)}$, Silaghi $D{ }^{(1)}$, Barbu I ${ }^{(1)}$, \\ lacoban $C^{(1)}$, Popescu $F^{(1)}$, Andrei $M^{(6)}$, Preda $E^{(6)}$, lacob $C^{(1)}$, \\ Dumitru I ${ }^{(2)}$, luncu $H^{(3)}$, Vezeanu $C^{(4)}$, Huber $V^{(5)}$
}

The monitoring studies carried out in the southern Romanian Carpathians (Retezat and Bucegi - Piatra Craiului Mts) provide a scientific support for long term ecosystem research (LTER). Their general objective is to characterize the air pollution and its potential effects upon forest ecosystems' status and biodiversity in close connection with climatic changes. Two monitoring networks were placed in selected forest ecosystems for each LTER site (11 plots in Retezat and 22 plots in Bucegi - Piatra Craiului, respectively). Both in Retezat and Bucegi - Piatra Craiului Mts, the distribution of mean ozone $\left(\mathrm{O}_{3}\right)$ concentrations are significantly correlated with altitude. The location (plot) has a significant influence on ozone concentration and in some cases the exposure period along the growing season has an influence. Ambient ozone $\left(\mathrm{O}_{3}\right)$ and ammonia $\left(\mathrm{NH}_{3}\right)$ concentrations were below toxicity levels for forest trees, their health status (crown condition) and volume growth being insignificantly affected. More than $45 \%$ of the rain events were acidic with $\mathrm{pH} \leq 5.5$, thus contributing to an increased $\mathrm{N}$ deposition on forest stands. In Retezat Mts crown condition was relatively better than in Bucegi - Piatra Craiului Mts. As a consequence, in 2009 European beech (Fagus sylvatica) was the least affected species, with a percentage of damaged trees (crown defoliation higher than 25\%) between 8.0\% (Retezat) and $9.8 \%$ (Bucegi - Piatra Craiului), followed by Norway spruce (Picea abies) with $12.9 \%$ (Retezat) and $27.7 \%$ (Bucegi - Piatra Craiului). The most affected species was Silver fir (Abies alba) with $31.6 \%$ of damaged trees (Bucegi-Piatra Craiului). In the last period, both European beech and conifers (Norway spruce and Silver fir) with high defoliation (damaged trees) had lower annual relative increment than trees with low defoliation (healthy trees). A definite trend regarding rapid environmental modifications is not evident and no significant reduction of biodiversity occurred. In addition, all the vegetation biodiversity components of the forest ecosystems are specific to the stand type's structures and local climate conditions, and no quantifiable consequences of specific air pollutants on ecosystems' diversity occurred.

Keywords: Long-term monitoring, Air pollution, Forest ecosystems, Crown condition, Growth, Biodiversity

\section{Introduction}

In Central Europe, since the late 1980s, levels of industrial pollutants have been considerably declining, but photochemical pollution, especially ozone $\left(\mathrm{O}_{3}\right)$ and other phytotoxic agents $\left(\mathrm{SO}_{2}, \mathrm{NO}_{2}, \mathrm{NH}_{3}\right)$, registered an important increase with damaging effects upon forests. At the same time the climate factors exert a permanent influence, temporal and spatial fluctuant, but determinant upon forest ecosystem status at
(1) Forest Research and Management Institute (ICAS), Eroilor Bld. 128, R-077190, Voluntari, Ilfov (Romania); (2) Valahia University, Carol I Bld. 2, R-130024, Targoviste, Dambovita (Romania); (3) Bucegi National Park, Principala Str. 21, Moroieni, Dambovita (Romania); (4) Piatra Craiului National Park, Toplitei Str. 150, Zarnesti, Brasov (Romania); (5) Transilvania University, Eroilor Bld. 129, R-500036, Brasov (Romania); (6) Bucharest University, M. Kogalniceanu Bld. 36-46, R-050170, Bucharest (Romania); (7) USDA - Forest Service, Pacific Southwest Research Station, Riverside, CA (USA); (8) "Stefan cel Mare" University, Universitatii Str. 13, R-720229, Suceava (Romania)

@, Ovidiu Badea (obadea@icas.ro)

Received: May 25, 2010 - Accepted: Nov 17, 2010

Citation: Badea O, Neagu S, Bytnerowicz A, Silaghi D, Barbu I, lacoban C, Popescu F, Andrei $M$, Preda $E$, lacob C, Dumitru I, luncu $\mathrm{H}$, Vezeanu C, Huber V, 2011. Long-term monitoring of air pollution effects on selected forest ecosystems in the Bucegi-

Piatra Craiului and Retezat Mountains, southern Carpathians (Romania). iForest 4: 49-60 [online: 2011-04-06] URL: http://www.sisef.it/iforest/show.php? id $=565$

not including social and economical component). Socio-economic development depends on appropriate management of natural resources based on ecological processes manifested by productive and supportive capacity. In order to meet these actual requirements, an interdisciplinary consortium focused on the relationship between ecology and social and economical systems was developed, leading to the foundation of Long Term Social and Ecological Research LTER Europe, of which Romania is an integrated part. Long term social and ecological research areas represents local or regional social and ecological complex, consisting of natural ecosystems, created, controlled or dominated by humans, specially designed and administered locally and/or regionally. These areas provide both the framework for multi- and transdisciplinary research programs and the space where the operational infrastructure, the policies and the adaptive management plans for ensuring social and economic sustainability can be projected, developed, tested and implemented.

The Carpathians are one of Europe's largest mountain ranges, a unique natural treasure of great beauty and ecological value, and home of several major rivers. They are an important ecological, economic, cultural and living environment in the very heart of Europe, and form the patrimony of many people and countries. This region is an im- 
Fig. 1 - Permanent plots network in Retezat LTER Site. portant reservoir for biodiversity, a sanctuary for many unique habitats and Europe's last refuge of well known large mammals (Grodzinska et al. 2004). The transition to the market economy, increasing possibilities of sustainable development based on the rich

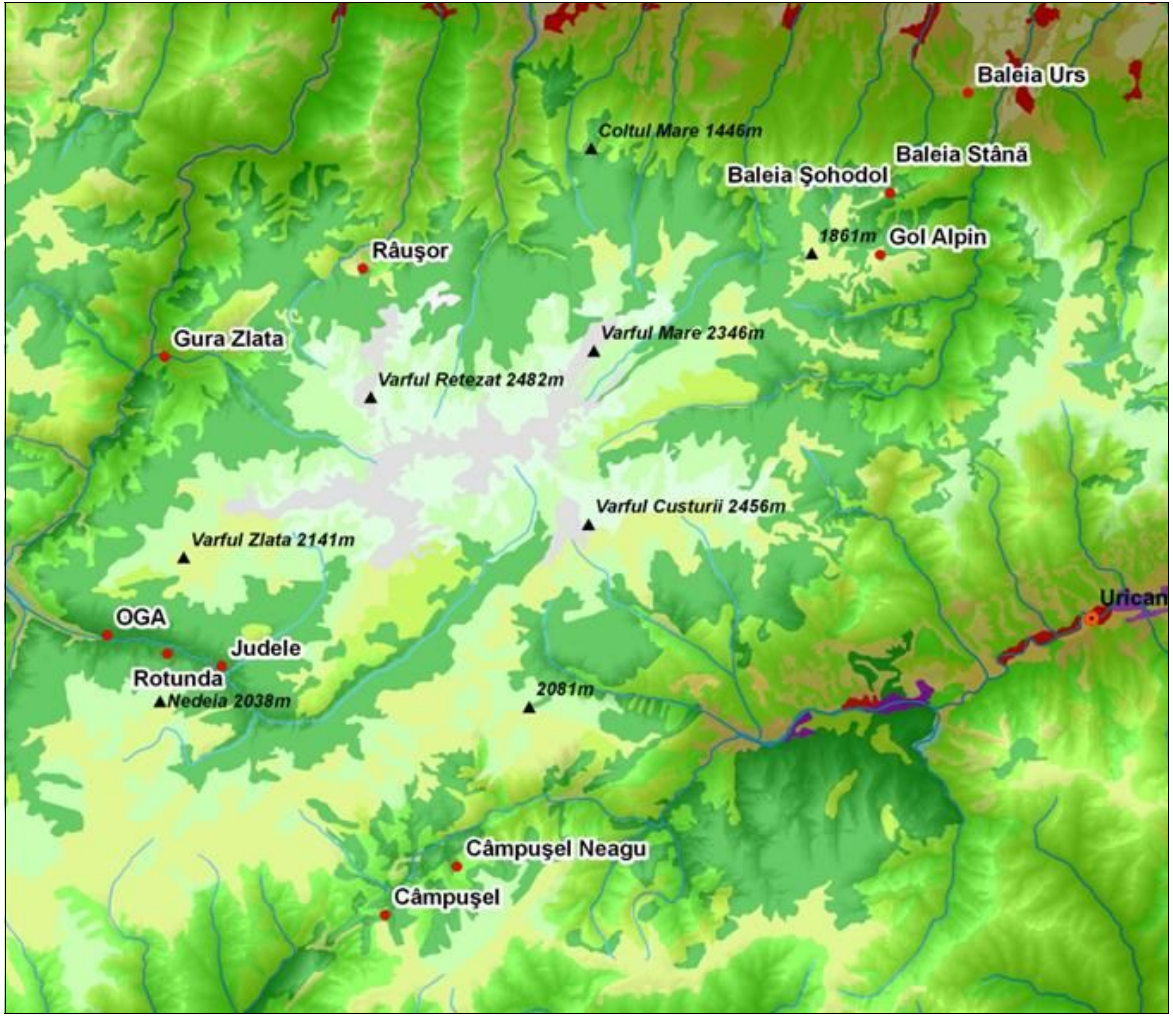

natural, environmental, cultural and human resources of the region are in a delicate balance with preserving its natural and cultural heritage for the future generations (Vadineanu et al. 2008). Retezat National Park (Retezat NP), Bucegi Natural Park (Bucegi
NP) and Piatra Craiului National Park (Piatra Craiului NP) represent social and ecological complex, are sites of the Long Term Social and Ecological Research [LT(S)ER-Europe], and are of a major national and European importance in specific researches concerning

Fig. 2 - Permanent plots network in Bucegi - Piatra Craiului LTER Site.

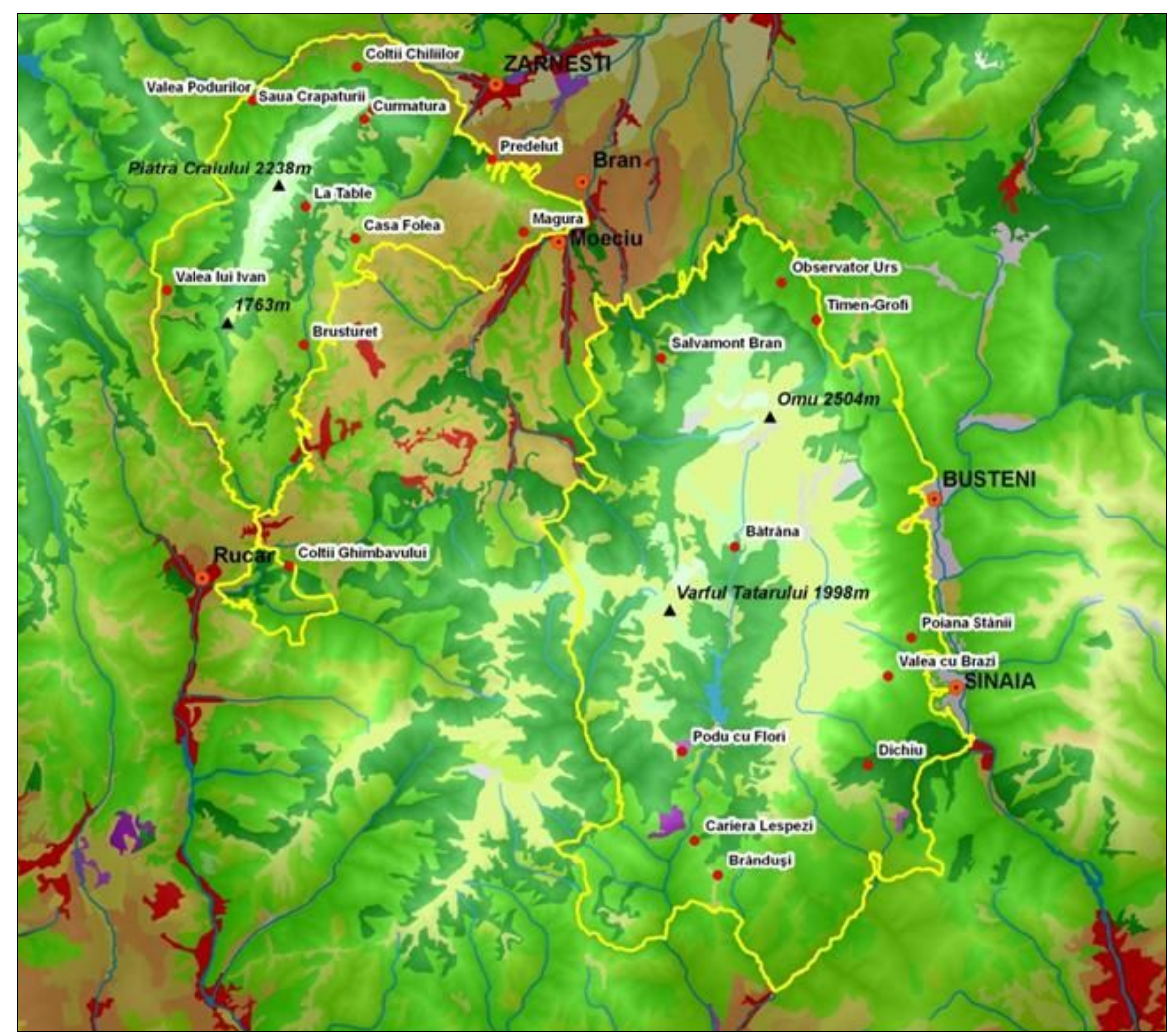


Tab. 1 - Research activities in Retezat LTER Site.

\begin{tabular}{|c|c|c|c|c|c|c|c|c|c|c|}
\hline $\begin{array}{l}\text { LTER } \\
\text { sites }\end{array}$ & $\begin{array}{l}\text { Altitude } \\
\text { a.s.l. (m) }\end{array}$ & $\begin{array}{l}\text { Main } \\
\text { species }\end{array}$ & $\begin{array}{l}\text { Growth } \\
\text { and Yield }\end{array}$ & $\begin{array}{l}\text { Crown } \\
\text { condition }\end{array}$ & $\begin{array}{c}\text { Soil } \\
\text { condition }\end{array}$ & $\begin{array}{l}\text { Analysis } \\
\text { of needles } \\
\text { and leaves }\end{array}$ & $\begin{array}{l}\text { Deposition } \\
\text { (bulk and } \\
\text { throughfall) }\end{array}$ & $\begin{array}{c}\text { Soil } \\
\text { Solution }\end{array}$ & $\begin{array}{c}\text { Bio- } \\
\text { diversity }\end{array}$ & $\begin{array}{c}\text { Air } \\
\text { Quality }\end{array}$ \\
\hline 1. Judele & 1190 & Picea abies & $\sqrt{ }$ & $\sqrt{ }$ & $\sqrt{ }$ & $\sqrt{ }$ & $\sqrt{ }$ & $\sqrt{ }$ & $\sqrt{ }$ & $\sqrt{ }$ \\
\hline 2. Rotunda & 1180 & $\begin{array}{l}\text { Picea abies, } \\
\text { other conifers }\end{array}$ & $\sqrt{ }$ & $\sqrt{ }$ & $\sqrt{ }$ & $\sqrt{ }$ & - & - & $\sqrt{ }$ & $\sqrt{ }$ \\
\hline 3. OGA & 1000 & $\begin{array}{l}\text { Fagus sylvatica, } \\
\text { Picea abies, } \\
\text { Abies alba }\end{array}$ & $\sqrt{ }$ & $\sqrt{ }$ & $\sqrt{ }$ & $\sqrt{ }$ & - & - & $\sqrt{ }$ & $\sqrt{ }$ \\
\hline 4. Gura Zlata & 800 & $\begin{array}{l}\text { Fagus sylvatica, } \\
\text { other broadleaves }\end{array}$ & $\sqrt{ }$ & $\sqrt{ }$ & $\sqrt{ }$ & $\sqrt{ }$ & $\sqrt{ }$ & $\sqrt{ }$ & $\sqrt{ }$ & $\sqrt{ }$ \\
\hline 5. Rausor & 1195 & $\begin{array}{l}\text { Picea abies, } \\
\text { Fagus sylvatica, } \\
\text { other broadleaves }\end{array}$ & $\sqrt{ }$ & $\sqrt{ }$ & $\sqrt{ }$ & $\sqrt{ }$ & - & - & $\sqrt{ }$ & $\sqrt{ }$ \\
\hline $\begin{array}{l}\text { 6. Baleia } \\
\text { Sohodol }\end{array}$ & 1300 & Picea abies & $\sqrt{ }$ & $\sqrt{ }$ & $\sqrt{ }$ & $\sqrt{ }$ & $\sqrt{ }$ & $\sqrt{ }$ & $\sqrt{ }$ & $\sqrt{ }$ \\
\hline 7. Baleia Stana & 1200 & $\begin{array}{l}\text { Picea abies, } \\
\text { Fraxinus excelsior, } \\
\text { other broadleaves }\end{array}$ & $\sqrt{ }$ & $\sqrt{ }$ & $\sqrt{ }$ & $\sqrt{ }$ & $\sqrt{ }$ & $\sqrt{ }$ & $\sqrt{ }$ & $\sqrt{ }$ \\
\hline 8. Baleia Urs & 800 & Fagus sylvatica & $\sqrt{ }$ & $\sqrt{ }$ & $\sqrt{ }$ & $\sqrt{ }$ & - & - & $\sqrt{ }$ & $\sqrt{ }$ \\
\hline $\begin{array}{l}\text { 9. Campusel } \\
\text { Neagu }\end{array}$ & 1100 & $\begin{array}{l}\text { Picea abies, } \\
\text { Fagus sylvatica }\end{array}$ & $\sqrt{ }$ & $\sqrt{ }$ & $\sqrt{ }$ & $\sqrt{ }$ & - & - & $\sqrt{ }$ & $\sqrt{ }$ \\
\hline 10. Campusel & 1400 & $\begin{array}{l}\text { Fagus sylvatica, } \\
\text { Picea abies }\end{array}$ & $\sqrt{ }$ & $\sqrt{ }$ & $\sqrt{ }$ & $\sqrt{ }$ & $\sqrt{ }$ & $\sqrt{ }$ & $\sqrt{ }$ & $\sqrt{ }$ \\
\hline 11. Baleia & 1600 & - & $\sqrt{ }$ & - & - & - & - & - & - & $\sqrt{ }$ \\
\hline
\end{tabular}

the status, productive capacity and support characterization of social and ecological systems in the context of climate change and air pollution effects.

The general objective of these research and monitoring activities in the Romanian Carpathians Mts is to characterize the air pollution and its potential effects upon forest ecosystems status and biodiversity in two LTER sites (Retezat and Bucegi - Piatra Craiului), in close connection with climate changes. The specific objectives of this paper are: i) to characterize the spatial and temporal distribution of selected air pollutants $\left(\mathrm{O}_{3}, \mathrm{NO}_{2}\right.$ and $\left.\mathrm{NH}_{3}\right)$; ii) to determine precipitation and throughfall acidity and chemical composition in selected forest sites; iii) to evaluate forest health status and biodiversity of forest vegetation; iv) to asses trees and forest stands growth in relation to crown condition.

\section{Study location}

Bucegi - Piatra Craiului and Retezat Mts are located in the Romanian southern Carpathians. Bucegi NP (32.500 ha), PiatraCraiului NP (13.800 ha) and Retezat NP (38.047 ha) are located in these mountains. In 2003, these areas were nominated as two ILTER Sites and in 2008 as LTER - Europe sites (Bucegi - Piatra Craiului and Retezat, respectively). The diversity and vast richness of Bucegi - Piatra Craiului and Retezat Massifs vegetation, with many endemic species and rich fauna which includes endangered species and unique plant communities like chamois, bear, lynx and wolf (Bytnerowicz et al. 2005) were the main reasons for the natural and national park status for Bucegi Piatra Craiului and Retezat Mts, respectively.

Two monitoring networks consisting in 11 (Retezat Mts) and 22 (Bucegi - Piatra Craiului) permanent plots (LTERp) were established in 2000 (Retezat) and 2006-2009 (Bucegi - Piatra Craiului). These plots were located within Bucegi - Piatra Craiului parks and both within and outside Retezat NP boundaries, in forest zone at elevation ranging from 800 to $1800 \mathrm{~m}$ (Fig. 1, Fig. 2, Tab. 1, Tab. 2). They were selected by considering the criteria of species composition, age distribution, and potential exposure to transboundary pollution. Monitoring plots were located in representative forest ecosystems, well exposed to incoming air masses allowing good measurements of air pollution status and its effects on forest ecosystems (Bytnerowicz et al. 2008).

\section{Methodology}

The plot area is 0.7 hectares (Fig. 3). It contains five permanent circular subplots of $500 \mathrm{~m}^{2}$ apiece, in which tree health status, dendrometric characteristics (species, DBH, height, Kraft class, quality, etc.), vegetation and biodiversity were regularly recorded. A number of destructive sampling methods (increment cores, leaves and soil samples) and several measurements of atmospheric deposition and soil solution were completed, but only in the buffer zone. Trees health (crown defoliation) was assessed annually during the study periods (between mid of July to the end of August), although with several gaps in the data series due to different causes. In every evaluation, all the dominant trees (predominant, dominant and codominant) were evaluated in accordance with the UN/ECE \& ICP-Forests (2004). Dendrometric measurements have been made in the year 2000 (Retezat NP), in 2006 (Bucegi NP) and in 2009 (Piatra Craiului NP), according to the methodological manual that was specially developed for long term ecological research (Badea 2008). Biodiversity of trees and herbaceous vegetation was assessed using Braun-Blanquet. Increment cores were taken from 25 to 30 trees located in the buffer zone of each LTERp (Fig. 3), both from trees within defoliation classes $0-1$ and 2-4. In cases of mixed stands (Norway spruce, silver fir and European beech), 10-15 increment cores have been taken from each of the main species. The annual volume growth and volume growth losses (due to the action of stress factors) have been determined based on the stands inventory and radial increment data. Information processing was done according to the methodological manual (Badea 2008).

Close to the long-term research plot, at the point of local maximum altitude and maximum exposure to air wind direction $(\mathrm{E}-\mathrm{V})$ special locations (trees) for exposure of passive filters (2 replicates) for $\mathrm{O}_{3}, \mathrm{NO}_{2}$ and $\mathrm{NH}_{3}$ were established (Bytnerowicz et al. 2008). These measurements were made 
Tab. 2 - Research activities in Bucegi - Piatra Craiului LTER site.

\begin{tabular}{|c|c|c|c|c|c|c|c|c|c|c|}
\hline $\begin{array}{l}\text { LTER } \\
\text { sites }\end{array}$ & $\begin{array}{l}\text { Altitude } \\
\text { a.s.l. (m) }\end{array}$ & $\begin{array}{l}\text { Main } \\
\text { species }\end{array}$ & $\begin{array}{l}\text { Growth } \\
\text { and Yield }\end{array}$ & $\begin{array}{l}\text { Crown } \\
\text { condition }\end{array}$ & $\begin{array}{c}\text { Soil } \\
\text { condition }\end{array}$ & $\begin{array}{c}\text { Analysis } \\
\text { of needles } \\
\text { and leaves }\end{array}$ & $\begin{array}{l}\text { Deposition } \\
\text { (bulk and } \\
\text { throughfall) }\end{array}$ & $\begin{array}{c}\text { Soil } \\
\text { Solution }\end{array}$ & $\begin{array}{c}\text { Bio- } \\
\text { diversity }\end{array}$ & $\begin{array}{c}\text { Air } \\
\text { Quality }\end{array}$ \\
\hline $\begin{array}{l}\text { 1. Salvamont } \\
\text { Bran }\end{array}$ & 1250 & Picea abies & $\sqrt{ }$ & $\sqrt{ }$ & $\sqrt{ }$ & $\sqrt{ }$ & $\sqrt{ }$ & $\sqrt{ }$ & $\sqrt{ }$ & $\sqrt{ }$ \\
\hline 2. Observator urs & 930 & $\begin{array}{l}\text { Picea abies, } \\
\text { Fagus sylvatica, } \\
\text { Abies alba }\end{array}$ & $\sqrt{ }$ & $\sqrt{ }$ & $\sqrt{ }$ & $\sqrt{ }$ & - & - & $\sqrt{ }$ & $\sqrt{ }$ \\
\hline 3. Timen-Grofi & 1000 & Picea abies & $\sqrt{ }$ & $\sqrt{ }$ & $\sqrt{ }$ & $\sqrt{ }$ & - & - & $\sqrt{ }$ & $\sqrt{ }$ \\
\hline 4. Poiana Stanii & 1300 & Fagus sylvatica & $\sqrt{ }$ & $\sqrt{ }$ & $\sqrt{ }$ & $\sqrt{ }$ & $\sqrt{ }$ & $\sqrt{ }$ & $\sqrt{ }$ & $\sqrt{ }$ \\
\hline 5. Valea cu Brazi & 1450 & Picea abies & $\sqrt{ }$ & $\sqrt{ }$ & $\sqrt{ }$ & $\sqrt{ }$ & - & - & $\sqrt{ }$ & $\sqrt{ }$ \\
\hline 6. Dichiu & 1250 & Fagus sylvatica & $\sqrt{ }$ & $\sqrt{ }$ & $\sqrt{ }$ & $\sqrt{ }$ & - & - & $\sqrt{ }$ & $\sqrt{ }$ \\
\hline 7. Brandusi & 1750 & Picea abies & $\sqrt{ }$ & $\sqrt{ }$ & $\sqrt{ }$ & $\sqrt{ }$ & - & - & $\sqrt{ }$ & $\sqrt{ }$ \\
\hline $\begin{array}{l}\text { 8. Cariera- } \\
\text { Lespezi }\end{array}$ & 1480 & Fagus sylvatica & $\sqrt{ }$ & $\sqrt{ }$ & $\sqrt{ }$ & $\sqrt{ }$ & - & - & $\sqrt{ }$ & $\sqrt{ }$ \\
\hline 9. Podu cu Flori & 1750 & Picea abies & $\sqrt{ }$ & $\sqrt{ }$ & $\sqrt{ }$ & $\sqrt{ }$ & $\sqrt{ }$ & $\sqrt{ }$ & $\sqrt{ }$ & $\sqrt{ }$ \\
\hline 10. Batrana & 1700 & Picea abies & $\sqrt{ }$ & $\sqrt{ }$ & $\sqrt{ }$ & $\sqrt{ }$ & - & - & $\sqrt{ }$ & $\sqrt{ }$ \\
\hline 11. Piatra Arsa & 1950 & - & - & - & $\sqrt{ }$ & - & - & - & - & $\sqrt{ }$ \\
\hline $\begin{array}{l}\text { 12. Valea } \\
\text { Podurilor }\end{array}$ & 1480 & $\begin{array}{l}\text { Abies alba, } \\
\text { Fagus sylvatica, } \\
\text { Picea abies }\end{array}$ & $\sqrt{ }$ & $\sqrt{ }$ & $\sqrt{ }$ & $\sqrt{ }$ & $\sqrt{ }$ & $\sqrt{ }$ & $\sqrt{ }$ & $\sqrt{ }$ \\
\hline $\begin{array}{l}\text { 13. Coltii } \\
\text { Chiliilor }\end{array}$ & 1576 & $\begin{array}{l}\text { Abies alba, } \\
\text { Picea abies, } \\
\text { Fagus sylvatica }\end{array}$ & $\sqrt{ }$ & $\sqrt{ }$ & $\sqrt{ }$ & $\sqrt{ }$ & - & - & $\sqrt{ }$ & $\sqrt{ }$ \\
\hline 14. Predelut & 812 & $\begin{array}{l}\text { Fagus sylvatica, } \\
\text { Abies alba }\end{array}$ & $\sqrt{ }$ & $\sqrt{ }$ & $\sqrt{ }$ & $\sqrt{ }$ & - & - & $\sqrt{ }$ & $\sqrt{ }$ \\
\hline 15. Magura & 883 & Fagus sylvatica & $\sqrt{ }$ & $\sqrt{ }$ & $\sqrt{ }$ & $\sqrt{ }$ & $\sqrt{ }$ & $\sqrt{ }$ & $\sqrt{ }$ & $\sqrt{ }$ \\
\hline 16. Casa Folea & 1410 & $\begin{array}{l}\text { Fagus sylvatica, } \\
\text { Picea abies }\end{array}$ & $\sqrt{ }$ & $\sqrt{ }$ & $\sqrt{ }$ & $\sqrt{ }$ & - & - & $\sqrt{ }$ & $\sqrt{ }$ \\
\hline 17. La Table & 1323 & Picea abies & $\sqrt{ }$ & $\sqrt{ }$ & $\sqrt{ }$ & $\sqrt{ }$ & - & - & $\sqrt{ }$ & $\sqrt{ }$ \\
\hline 18. Curmatura & 1495 & Picea abies & $\sqrt{ }$ & $\sqrt{ }$ & $\sqrt{ }$ & $\sqrt{ }$ & - & - & $\sqrt{ }$ & $\sqrt{ }$ \\
\hline $\begin{array}{l}\text { 19. Valea lui } \\
\text { Ivan }\end{array}$ & 903 & Picea abies & $\sqrt{ }$ & $\sqrt{ }$ & $\sqrt{ }$ & $\sqrt{ }$ & $\sqrt{ }$ & $\sqrt{ }$ & $\sqrt{ }$ & $\sqrt{ }$ \\
\hline 20. Brusturet & 1432 & $\begin{array}{l}\text { Fagus sylvatica, } \\
\text { other broadleaves }\end{array}$ & $\sqrt{ }$ & $\sqrt{ }$ & $\sqrt{ }$ & $\sqrt{ }$ & - & - & $\sqrt{ }$ & $\sqrt{ }$ \\
\hline $\begin{array}{l}\text { 21. Coltii } \\
\text { Ghimbavului }\end{array}$ & 850 & $\begin{array}{l}\text { Picea abies, } \\
\text { other conifers }\end{array}$ & $\sqrt{ }$ & $\sqrt{ }$ & $\sqrt{ }$ & $\sqrt{ }$ & - & - & $\sqrt{ }$ & $\sqrt{ }$ \\
\hline $\begin{array}{l}\text { 22. Saua } \\
\text { Crapaturii }\end{array}$ & 1012 & - & - & - & - & - & - & - & - & $\sqrt{ }$ \\
\hline
\end{tabular}

monthly, during vegetation seasons, and the chemical analysis of the passive filters was carried out in the first years at USDA-Forest Service laboratory, in Riverside, and since 2009 in ICAS laboratory.

Wet and dry deposition (under canopy and in open field) was sampled on a total of 12 plots, of which 6 in Bucegi-Piatra Craiului and 6 in Retezat. In each plot, eight collectors were placed in the buffer zone, on each side of its centers, and on the same level curve (Barbu \& Iacoban 2008). Monthly, the samples of atmospheric deposition and soil solution were collected and analyzed in the laboratory of ICAS. In addition, sampling methodology and chemical analysis methods were adopted and applied according to the methodological manual (Badea 2008). SPSS software was used for processing the experimental data.

\section{Results and discussions}

\section{Air quality}

On Retezat and Bucegi-Piatra Craiului LTER sites, the ozone concentrations were measured during the growing season (15 June -15 October) using passive samplers. In most of the Retezat NP's research plots, the ambient ozone concentration followed an irregular distribution. At the beginning of summer (15 June - 15 July), the highest seasonal average values were registered (Fig. 4). A second peak, but smaller than the first one, was recorded between mid August and mid September. Exceptions were registered in four sites (OGA, Gura Zlata, Rausor and Judele) where the second peak was recorded at the end of the exposure period (15 September-15 October). Also, an increase of ozone concentration correlated with altitude was noticed both in terms of exposure period and growing season levels (Fig. 5).

Compared with the results registered in 2000-2002 period (Bytnerowicz et al. 2005), in 2009 ozone concentrations on altitudinal strata were lower, but slightly higher than in 2002 (Fig. 6). The correlation between this multiannual ozone distributions and altitude was not statistically significant $(\mathrm{p}>0.05)$. The correlation coefficient values $(r)$ vary between $0.469, \mathrm{p}>0.05$ (in 2009) and 0.601, $\mathrm{p}>0.05$ (in 2002). Also, one-way ANOVA shows that location had a significant influence on ozone concentrations $(\mathrm{F}=31.25, \mathrm{p}=$ 0.01 , while exposure period had no significant influence $(\mathrm{F}=0.860, \mathrm{p}=0.470)$.

The ammonia concentrations $\left(\mathrm{NH}_{3}\right)$ showed the lowest values at the beginning of summer, when they were $<1 \mu \mathrm{g} \mathrm{m}^{-3}$ (exception - Gura Zlata); maximum values were re- 
Fig. 3 - Design of long term ecological research plot (LTERp).

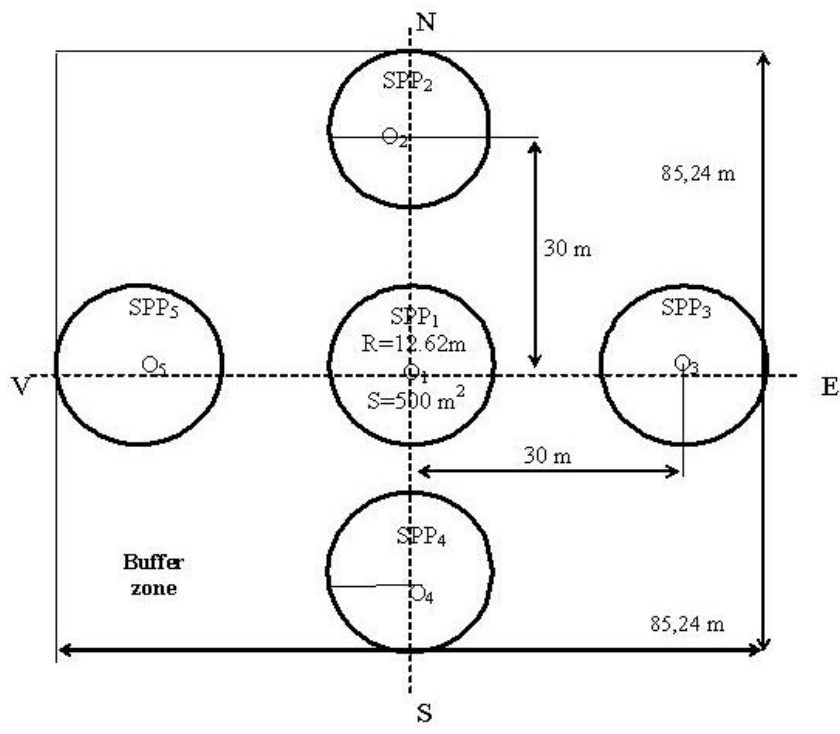

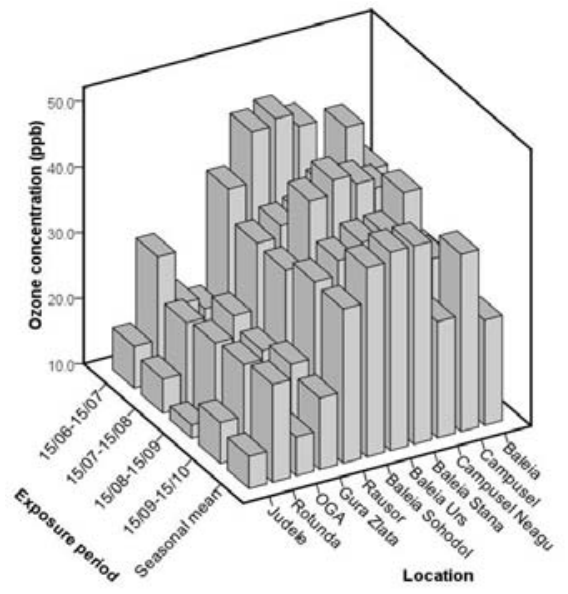

Fig. 4 - Spatial and temporal distribution of ozone concentration in 2009 growing season (Retezat NP).

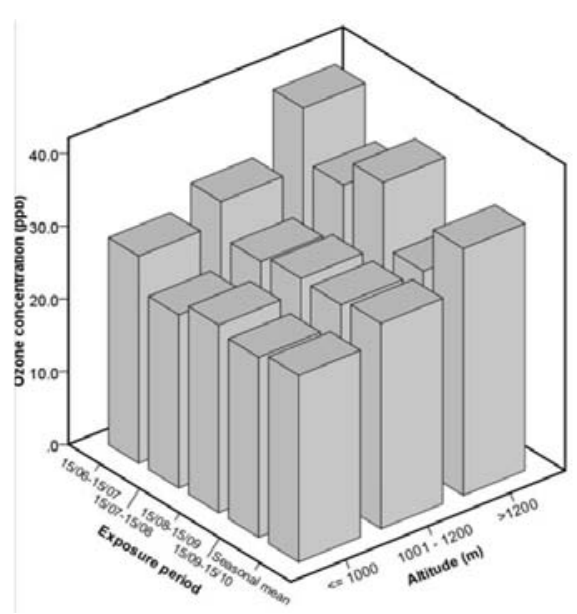

Fig. 5 - Variation of ozone concentration in relation to exposure period and altitude during the 2009 growing season (Retezat NP).

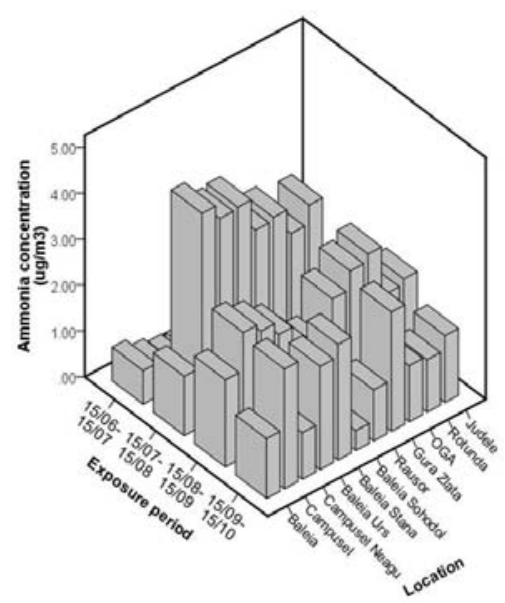

Fig. 7 - Monthly averages of the ambient $\mathrm{NH}_{3}$ concentrations in 2009 (Retezat NP). One-way ANOVA showed no significant influence of location $(\mathrm{p}=0.697)$ and significant influence of time $\left(\mathrm{p}=1.5 \mathrm{E}^{-5}\right)$.

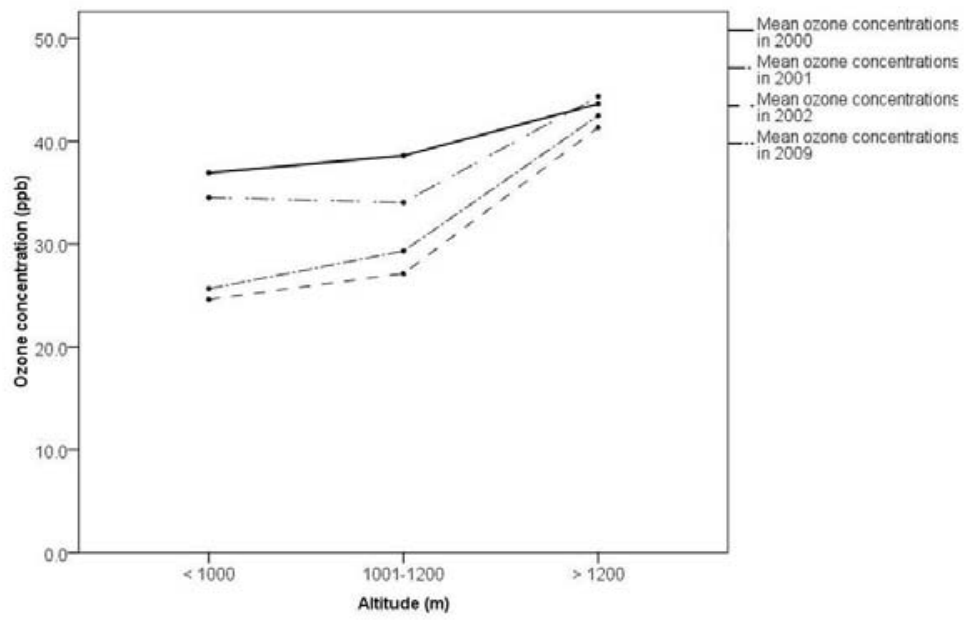

Fig. 6 - Distribution of ozone concentration by altitude during the period 2000-2002 and 2009 (Retezat NP). Pearson correlation coefficient between ozone concentration and altitude ranged from $r=0.469, \mathrm{p}>0.05$ (in 2009) to $r=0.601, \mathrm{p}>0.05$ (in 2002) - no significant correlation.
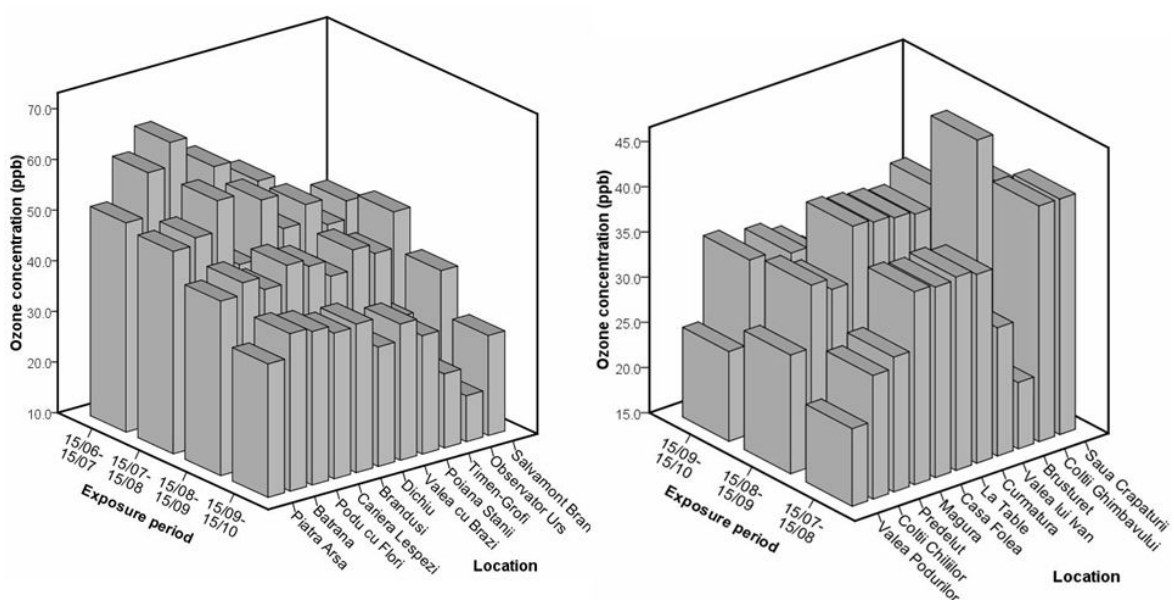

Fig. 8 - Spatial and temporal distribution of ozone concentration in 2009 growing season in Bucegi NP (left) and in Piatra Craiului NP (right). 


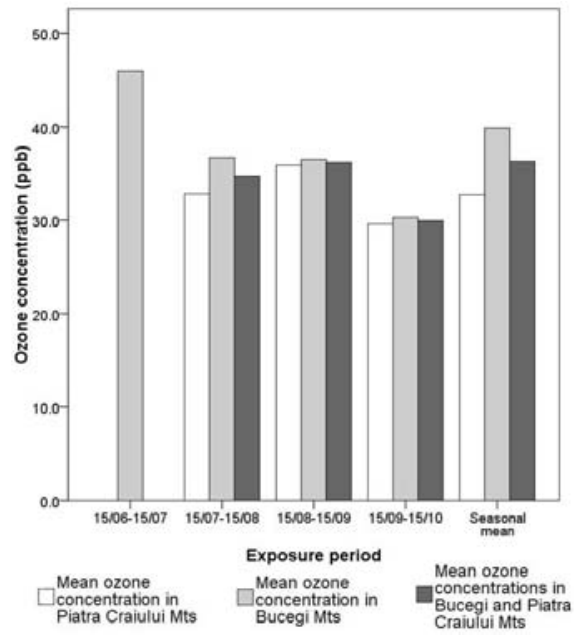

Fig. 9 - Temporal distribution of ozone concentrations in Bucegi NP, Piatra Craiului NP and Bucegi-Piatra Craiului LTER Site. No data were collected in Piatra Craiului Mountains in the 15/06-15/07 period.

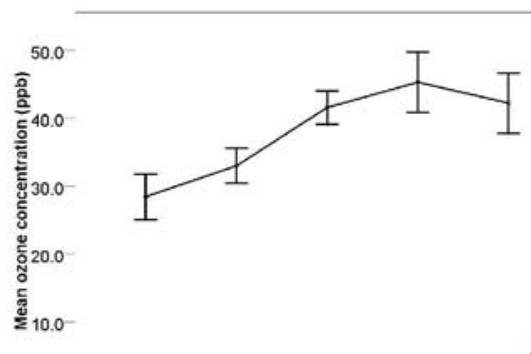

A

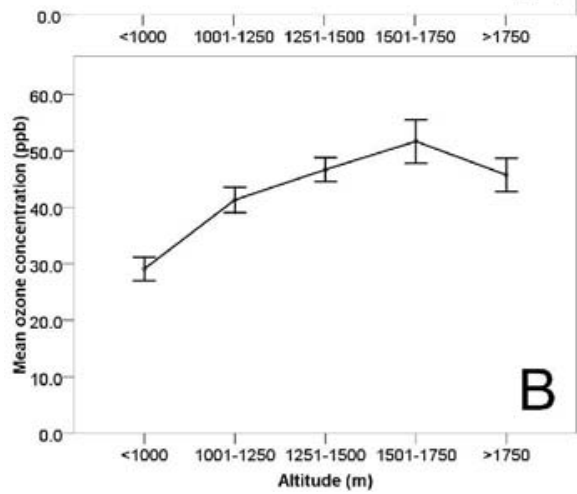

Fig. 10 - Distribution of ozone concentration by altitude in 2009 - Bucegi - Piatra Craiului LTER Site (A) and during the period 20062009 - Bucegi NP (B). Pearson correlation coefficient between ozone concentration and altitude in Bucegi NP is between $r=0.821$, $\mathrm{p}<0.01$ (in 2007) and $r=0.880, \mathrm{p}<0.01$ (in 2006 - significant correlation at $\mathrm{p}=$ $0.01)$. Error bars: $95 \% \mathrm{CI}$.

corded in midsummer (15 July - 15 August). Towards the end of the season (September October), and sometimes during it, the majority of ammonia concentrations were around $2 \mu \mathrm{g} \mathrm{m}^{-3}$, and seldom between $1-2 \mu \mathrm{g}$ $\mathrm{m}^{-3}$ (Fig. 7)

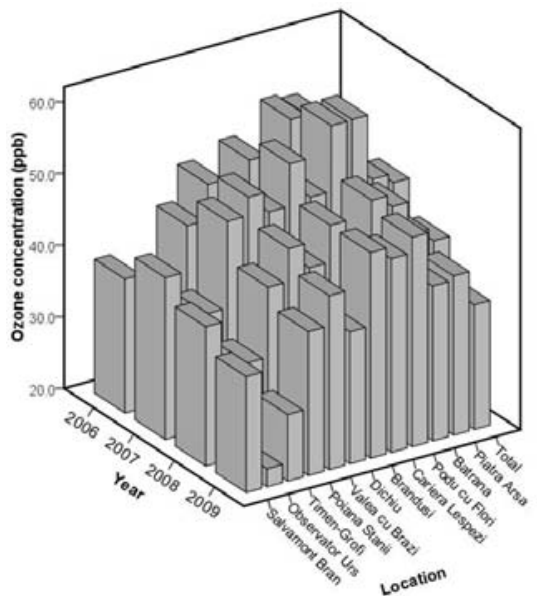

Fig. 11 - Distribution of ozone concentration by location during the period 2006-2009 (Bucegi NP).

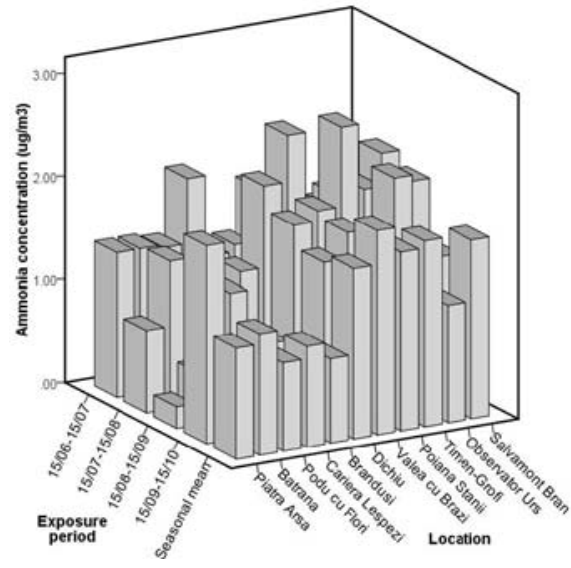

Fig. 12 - Monthly averages of the ambient $\mathrm{NH}_{3}$ concentrations in 2009 (Bucegi NP). One-way ANOVA showed significant influence of location $\left(\mathrm{p}=4.1 \mathrm{E}^{-4}\right)$ and no significant influence of time $(\mathrm{p}=0.119)$.

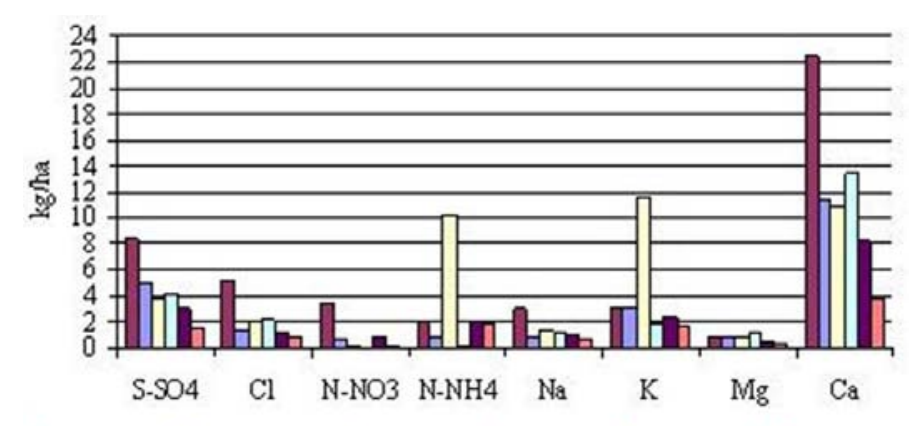

$\square$ open field $\square$ unde canopy $\square$ Soil $10 \mathrm{~cm} \square$ Soil $20 \mathrm{~cm} \square$ Soil $60 \mathrm{~cm} \square$ Soil $60 \mathrm{~cm}$

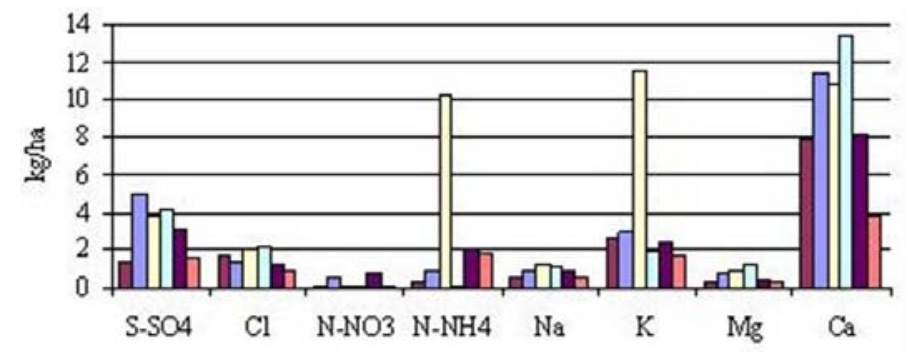

Fig. 14 - Fluxes of ions (deposition and soil solution) during the growing season 2009 in Bucegi NP, plot Podu cu Flori (Picea abies).

\section{Dopen field $\square$ unde caropy $\square$ Sol $10 \mathrm{~cm} \square$ Soil $20 \mathrm{~cm} \square$ Soil $40 \mathrm{~cm} \square$ Soil $60 \mathrm{~cm}$}

One-way ANOVA shows that exposure period significantly influenced the ammonia concentrations $(\mathrm{F}=11.379, \mathrm{p} \leq 0.05)$ Location had no significant influence $(\mathrm{F}=0.724$, $p \geq 0.05$ - Fig. 7). The significant influence of exposure period on ammonia concentration confirms the intensity of touristic activities along Retezat NP in different vegetation season periods.

Relative to the 2000-2001 period, in 2009 the mean $\mathrm{NH}_{3}$ concentrations was significantly reduced from $5.92 \mu \mathrm{g} \mathrm{m}^{-3}$ (2001) to 1.97 $\mu \mathrm{g} \mathrm{m}^{-3}$ (2009). This can be explained by the decreasing human and industrial activities in the area, and by high altitude pollution.

During the year 2009, Bucegi-Piatra Craiului LTER site had a decreasing distribution of ozone concentration, from $46 \mathrm{ppb}$ at the beginning of the summer season (15 June - 15 July) to $29.9 \mathrm{ppb}$ by the end of the growing season (15 September -15 October Fig. $8 \mathrm{AB}$ ).

In the Piatra Craiului NP the maximum ozone concentration was recorded in mid 
Fig. 15 - Fluxes of ions (deposition) during the growing season 2009 in Piatra Craiului NP, plot Valea Podurilor

(Fagus sylvatica and Picea abies mixed stand).

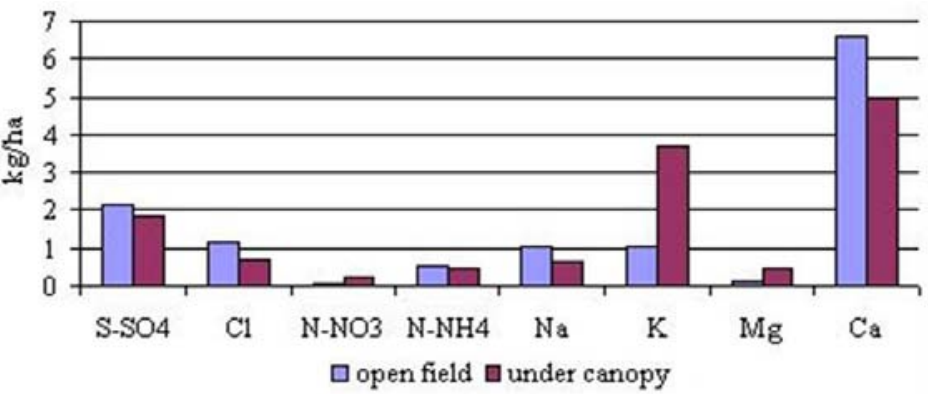

Fig. 16 - Fluxes of ions (deposition and soil solution) during the growing season 2009 in Piatra Craiului $\mathrm{N}$ $\mathrm{P}$, plot Magura

(Fagus sylvatica).

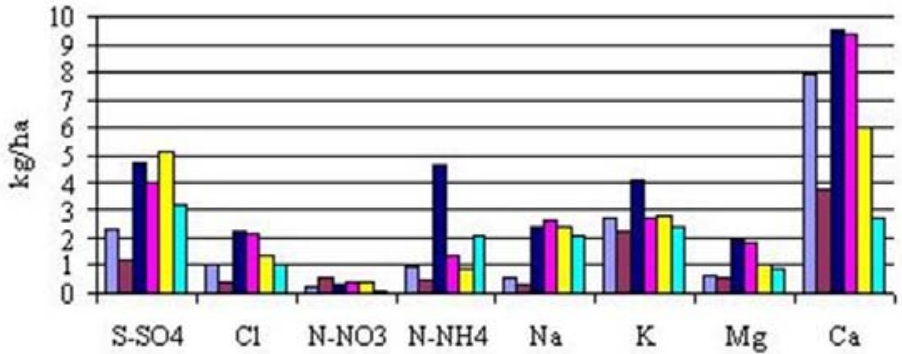

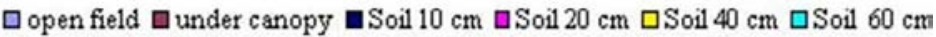

Fig. 17 - Fluxes of ions (deposition and soil solution) during the growing season 2009 in Retezat NP, site Gura Zlata (Fagus sylvatica).

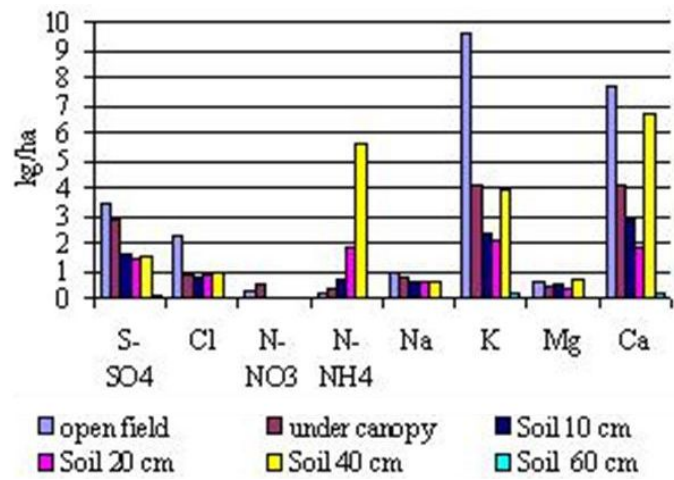

Fig. 18 - Fluxes of ions (deposition) during the growing season 2009 in Retezat NP, site Judele (Picea abies).

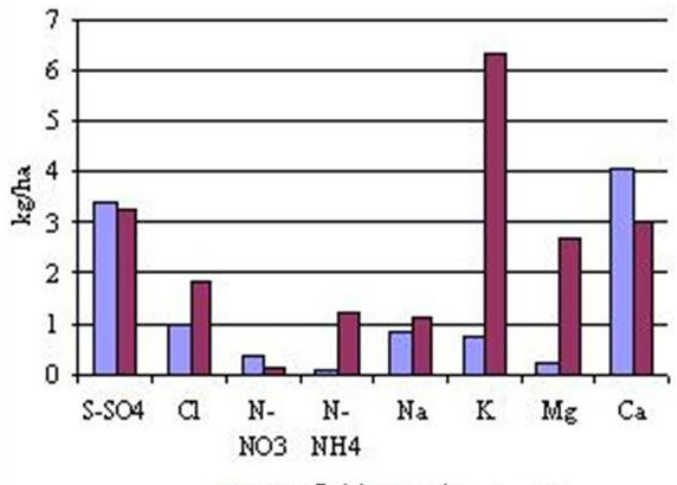

$\square$ open field $\square$ under canopy
August until September (35.9 ppb) compared to Bucegi NP when the maximum value (46 $\mathrm{ppb})$ was registered at the beginning of the summer season (15 June-15 July - Fig. 9). In general, for the entire season and for the entire LTER site the average value was 36.3 $\mathrm{ppb}$. The seasonal mean values for each location were between $21.4 \mathrm{ppb}$ (Brusturet) and $39.3 \mathrm{ppb}$ (Coltii Ghimbavului) in Piatra Craiului Mts and between $22.5 \mathrm{ppb}$ (Observator Urs) and $54.6 \mathrm{ppb}$ (Cariera Lespezi) in Bucegi Mts. The average value for the entire season was $32.7 \mathrm{ppb}$ in Piatra Craiului $\mathrm{Na}$ tional Park, compared to $39.9 \mathrm{ppb}$ in the Bucegi NP (Fig. 8A and B). It is worth noticing that the variation coefficients of ozone concentration were significantly lower in Piatra Craiului than in Bucegi Mts $\left(\mathrm{S}_{\%}=\right.$ $17.4 \%$ compared to $23.2 \%$, respectively).

In 2009, similar to Retezat LTER site, in Bucegi - Piatra Craiului an increase of ambient ozone concentrations with altitude was noticed (Fig. 10A). The same situation was encountered in Bucegi Mountains during the period 2006-2009 (Fig. 10B).

One way ANOVA shows a significant influence of location and exposure periods on ozone concentrations $(\mathrm{F}=16.950, \mathrm{p}=0.01$ and $\mathrm{F}=13.981, \mathrm{p}=0.01$, respectively). Overall, during this period (2006 to 2009) the spatial and temporal variation of ozone in the Bucegi Mts was relatively low $\left(\mathrm{s}_{\%}=\right.$ $20.6 \%$ ), denoting increased stability.

Compared with the previous period (20062008), in 2009 the seasonal average of ambient ozone concentrations in Bucegi Mts was the lowest at most locations (except Podu cu Flori - Fig. 11). The maximum annual average was registered in 2007, when the temperatures during the growing season were very high (over $35^{\circ} \mathrm{C}$ ), followed by a small decrease in the following years, 2008 and 2009.

At these two LTER sites, representing the Southern Romanian Carpathians, the ozone values were in accordance with ranges of annual seasonal means measured in previous periods (1997 to 1999) for the Romanian Carpathians (Bytnerowicz et al. 2005).

The average ammonia $\left(\mathrm{NH}_{3}\right)$ concentrations in 2009 were low for most locations in Bucegi Mts (Fig. 12). However, elevated levels were occasionally registered in Poiana Stanii (especially between 15 August and 15 September - $2.64 \mu \mathrm{g} \mathrm{m}^{-3}$ ). This spike in $\mathrm{NH}_{3}$ was probably caused by some local emissions from touristic activities, agricultural operations or biological fertilization. Oneway ANOVA showed a significant influence of location $(\mathrm{F}=4.196, \mathrm{p} \leq 0.01)$ and no significant influence of time $(\mathrm{F}=0.378, \mathrm{p}>$ $0.05)$ on $\mathrm{NH}_{3}$ concentrations.

Generally, in 2009 seasonal mean concentrations of $\mathrm{NH}_{3}$ in Piatra Craiului Mts were higher than in Bucegi Mts $\left(2.38 \mu \mathrm{g} \mathrm{m}^{-3}\right.$ vs $1.36 \mu \mathrm{g} \mathrm{m}^{-3}$ ). The averages over the whole 
LTER site (Bucegi-Piatra Craiului) were below $2.0 \mu \mathrm{g} \mathrm{m}^{-3}\left(1.8 \mu \mathrm{g} \mathrm{m}^{-3}\right)$.

During the period 2006-2009, the annual means of $\mathrm{NH}_{3}$ in Bucegi Mts were the lowest in $2007\left(1.00 \mu \mathrm{g} \mathrm{m}^{-3}\right)$. At location level, these values were between $0.66 \mu \mathrm{g} \mathrm{m}^{-3}$ and $2.46 \mu \mathrm{g} \mathrm{m}^{-3}$ (in 2006) and between $0.59 \mu \mathrm{g}$ $\mathrm{m}^{-3}$ and $1.78 \mu \mathrm{g} \mathrm{m}^{-3}$ (in 2007). Nevertheless, the concentrations were much lower than in Retezat mountains during the period 2000 to 2002 (Bytnerowicz et al. 2005) and in 2009.

Both in Retezat and Bucegi-Piatra Craiului Mts all of $\mathrm{NH}_{3}$ concentrations were below phytotoxic levels (Bytnerowicz et al. 1998). In the long term they may contribute to increasing nitrogen deposition (Bytnerowicz et al. 2005).

\section{Atmospheric deposition}

In 2009 growing season, $\mathrm{S}_{-} \mathrm{SO}_{4}$ inputs in the open field (bulk deposition) vary from 2 to about $8 \mathrm{~kg} \mathrm{ha}^{-1}$. The highest values were measured in Bucegi NP (Poiana Stanii and Podu cu Flori LTERp - Fig. 13, Fig. 14), and the lowest values were found in Piatra Craiului National Park, at Salvamont Bran and Valea Podurilor (Fig. 15).

Throughfall input of sulphate varied in relation to bulk deposition, with values from 3 to $6 \mathrm{~kg} \mathrm{ha}^{-1}$. In the areas located far from roads and populated places, the fluxes under the canopy were lower than in the open field (Valea Podurilor and Magura, and in Gura Zlata and Judele (Fig. 15, Fig. 16, Fig. 17 and Fig. 18).

As $\mathrm{SO}_{4}^{-2}$ shows low interaction with plant canopies (Bredemeyer 1988), the $\mathrm{SO}_{4}$ enrichment in throughfall shows an accumulation of dry depositions between two rain events (Lindberg \& Lovett 1992). Low enrichment factors (ratio between fluxes under the canopy and in the open field) indicate that studied areas are less polluted. In 2009 the $\mathrm{S}_{-} \mathrm{SO}_{4}$ input increased two times relative to 2000-2002 (Badea et al. 2002).

Nitrogen input was very low and ranged from $0.2 \mathrm{~kg} \mathrm{ha}^{-1}$ (Podu cu Flori, Valea Podurilor, Magura, and Gura Zlata) to $3.5 \mathrm{~kg}$ $\mathrm{ha}^{-1}$ (Poiana Stanii, located on the slope exposed to the Prahova Valley with high density of traffic). There was a similar pattern between deposition of $\mathrm{NO}_{3}$ and $\mathrm{NH}_{4}$; the range of $\mathrm{N}-\mathrm{NH}_{4}$ being much higher than $\mathrm{N}$ $\mathrm{NO}_{3}$ deposition. At different soil depths N$\mathrm{NO}_{3}$ increased in Campusel and was nearly constant in Magura or decreased in Poiana Stanii; $\mathrm{N}_{-} \mathrm{NH}_{4}$ increased in soil and reached a maximum of $4-10 \mathrm{~kg} \mathrm{ha}^{-1}$ in Poiana Stanii and Gura Zlata. Throughfall was dominated by $\mathrm{N}-\mathrm{NH}_{4}$ mainly on plots located at high altitudes. Bulk precipitation of $\mathrm{N}^{-\mathrm{NH}_{4}}$ varied from $0.5 \mathrm{~kg} \mathrm{ha}^{-1}$ to $2-4 \mathrm{~kg} \mathrm{ha}^{-1}$ (Fig. 13, Fig. 15, Fig. 18 and Fig. 19). This input was enhanced by to 2-8 times at Podu cu Flori location by the addition of dry deposition of $\mathrm{NH}_{4}$ like particles or aerosols.
In some sites, throughfall content of $\mathrm{NO}_{3}$ and $\mathrm{NH}_{4}$ was lower than in bulk deposition (Poiana Stanii, Campusel, and Magura) possibly due to direct canopy uptake of $\mathrm{NO}_{3}$ or $\mathrm{NH}_{4}$ (Brumme et al. 1992). Sites receiving very low levels of nitrogen in bulk precipitation registered insignificant amounts in throughfall, too (Dise et al. 1998).

Base cations $\left(\mathrm{K}^{+}, \mathrm{Mg}^{+2}\right.$ and $\left.\mathrm{Ca}^{+2}\right)$ fluxes in the growing season showed high amount of $\mathrm{K}$ leached from the canopy in all plots; $\mathrm{Mg}^{+2}$ showed low amounts not only in the atmospheric deposition but also in the gravitational water in soils. $\mathrm{Ca}^{+2}$ input was estimated at 5-7 $\mathrm{kg} \mathrm{ha}^{-1}$. The throughfall $\mathrm{Ca}^{+2}$ fluxes were not very much modified as compared with those registered in the open field, probably due to reactions with acidic ions. In soil solution, the $\mathrm{Ca}^{+2}$ content was quite high, mainly in the plots located on the soils formed on limestone at Campusel $(18-20 \mathrm{~kg}$ $\mathrm{ha}^{-1}$ ). On soil originated from granite parent material (Gura Zlata), the amount of $\mathrm{Ca}^{+2}$ in the gravitational water on the profile decreased from 3 to $2 \mathrm{~kg} \mathrm{ha}^{-1}$ in the first $20 \mathrm{~cm}$ and increased at $7 \mathrm{~kg} \mathrm{ha}^{-1}$ at $40 \mathrm{~cm}$.

In the Bucegi - Piatra Craiului LTER site the monitoring of atmospheric depositions in the period 2006-2008 allows comparisons with the growing season 2009. The input of $\mathrm{S}^{-\mathrm{SO}_{4}}$ in open field was variable from $1.1 \mathrm{~kg}$ $\mathrm{ha}^{-1}$ (Podu cu Flori) to $3.7 \mathrm{~kg} \mathrm{ha}^{-1}$ (Salvamont Bran) and $3.1 \mathrm{~kg} \mathrm{ha}^{-1}$ (Poiana Stanii). No visible trend of the main ions was detected, because of the high variability due to variable weather conditions and rainfall regimes.

In comparison with the results obtained at the beginning of the monitoring program in Retezat NP (Badea et al. 2002) the amounts of sulphur in 2009 were similar to those determined in 2000 at Judele and nearly double (4-6 kg ha $\left.{ }^{-1}\right)$ in Judele, Gura Zlata and Campusel.

Concerning $\mathrm{Cl}, \mathrm{N}^{-\mathrm{NO}_{3}}$ and $\mathrm{N}-\mathrm{NH}_{4}$, no significant changes were observed. Also, the input of the basic cations $\mathrm{K}, \mathrm{Mg}, \mathrm{Ca}$ was higher in 2009 than in 2000.

Using bulk depositions, throughfall and soil water collected in the growing season in these two LTER sites, it was possible to show the influence of the canopy on the mineral ions fluxes.

\section{Forest condition}

In 2009, 2385 and 876 trees were assessed in Bucegi - Piatra Craiului LTER-site (20 permanent plots) and Retezat (10 permanent plots), respectively. Several significant differences regarding the damaged trees population (defoliation classes 2-4, crown defoliation $>25 \%$ ) were registered both among plots and between the two LTER sites (Tab. 3 and Tab. 4). As a result, for all species, the share of damaged trees (defoliation classes $2-4)$ was much lower in Retezat (12.1\%) than in Bucegi - Piatra Craiului (22.5\%). The
Tab. 3 - Trees crown defoliation share for all plots in 2009 (Retezat LTER site).

\begin{tabular}{lrr}
\hline \multirow{1}{*}{\multicolumn{1}{c}{ Plot }} & \multicolumn{2}{c}{$\begin{array}{c}\text { Group of defoliation } \\
\text { classes }\end{array}$} \\
\cline { 2 - 3 } & $\mathbf{0 - 1}$ & $\mathbf{2} \mathbf{- 4}$ \\
\hline Judele & 84.3 & 15.7 \\
Rotunda & 77.5 & 22.5 \\
OGA & 92.6 & 7.4 \\
Gura Zlata & 100.0 & 0.0 \\
Rausor & 91.6 & 8.4 \\
Baleia Sohodol & 90.8 & 9.2 \\
Baleia Stana & 79.0 & 21.0 \\
Baleia Urs & 91.3 & 8.7 \\
Campusel Neagu & 74.3 & 25.7 \\
Campusel & 91.7 & 8.3 \\
Total & 87.9 & 12.1 \\
\hline
\end{tabular}

damage intensity was higher in Bucegi NP $(28.0 \%)$ than in Piatra Craiului NP $(17.5 \%$ Tab. 4). Individually, the health status of European beech (Fagus sylvatica) was almost the same in Retezat $(8.0 \%)$ and in Bucegi - Piatra Craiului (9.8\%), but Norway spruce (Picea abies) was healthier in Retezat than in Bucegi - Piatra Craiului (12.9\% and $27.7 \%$, respectively - Tab. 5).

Tab. 4 - Trees crown defoliation share for all plots in 2009 (Bucegi-Piatra Craiului LTER site).

\begin{tabular}{lcr}
\hline \multicolumn{1}{c}{ Plot } & $\begin{array}{c}\text { Group of defoliation } \\
\text { classes }\end{array}$ \\
\cline { 2 - 3 } & $\mathbf{0 - 1}$ & $\mathbf{2 - 4}$ \\
\hline Salvamont Bran & 81.4 & 18.6 \\
Observator Urs & 81.1 & 18.9 \\
Timen-Grofi & 60.7 & 39.3 \\
Poiana Stanii & 85.7 & 14.3 \\
Valea cu Brazi & 65.4 & 34.6 \\
Dichiu & 76.8 & 23.2 \\
Brandusi & 45.7 & 54.3 \\
Cariera Lespezi & 76.4 & 23.6 \\
Podu cu Flori & 70.4 & 29.6 \\
Batrana & 82.4 & 17.6 \\
Bucegi Natural Park & 72.0 & 28.0 \\
Valea Podurilor & 74.4 & 25.6 \\
Coltii Chiliilor & 70.7 & 29.3 \\
Predelut & 97.1 & 2.9 \\
Magura & 93.1 & 6.9 \\
Casa Folea & 88.8 & 11.2 \\
La Table & 77.5 & 22.5 \\
Curmatura & 68.4 & 31.6 \\
Valea lui Ivan & 89.6 & 10.4 \\
Brusturet & 94.4 & 5.6 \\
Coltii Ghimbavului & 91.2 & 8.8 \\
Piatra Craiului & 83.0 & 17.0 \\
National Park & & \\
Total Bucegi- Piatra & 77.5 & 22.5 \\
Craiului & & \\
\hline & &
\end{tabular}


Fig. 19 - Fluxes of ions (de- $\mathrm{kg} / \mathrm{ha}$ position) during the growing season 2009 in Retezat NP, site Campuse (Fagus sylvatica and Abies alba mixed stand).

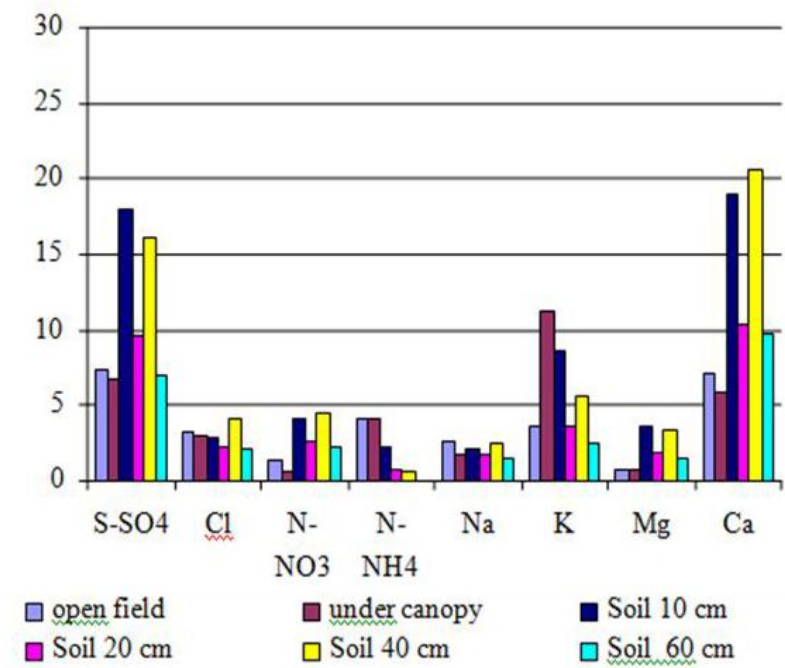

In Retezat Mts, compared with results in the 2000-2002 period, the crown condition for all species had considerably improved from $16.1 \%$ in 2002 to $12.1 \%$ in 2009 (Fig. 20). In addition, Norway spruce and European beech showed a better crown condition in 2009 as compared with 2002, with the share of damaged trees (defoliation classes 2-4) decreasing from $17.9 \%$ in 2002 to $12.9 \%$ in 2009 and from $11.8 \%$ in 2002 to $8.0 \%$ in 2009 .

Nevertheless, in 2009, some plots (Campusel Neagu, Rotunda and Baleia Stana) registered over $20 \%$ of damaged trees (Tab. 3 ). This can be explained by canopy cover reducing, ageing factor and extreme environment conditions.

The increased share of damaged trees is explained by: degradation processes of low density and high age (more than 120 years) forest stands: extreme conditions of soil (with surfaced rocks fragments), with average to low productivity; and presence of secondary deciduous species with a very poor crown condition. Even resinous species and Norway spruce especially showed a high rate of damaged trees, because many trees were assessed at the lower limit (crown defoliation $30-35 \%$ ) of defoliation class 2 (moderately affected damaged class). These trees showed very active migration intensity in healthy group classes (defoliation $\leq 25 \%$ Badea et al. 1998). The other stands with a small share of damaged trees were mostly in the early development stages and have a superior stability and vitality.

In Bucegi Mts, compared to the previous period (2006-2008), the share of damaged trees for all species slowly decreased from $33.9 \%$ in 2008 to $28.0 \%$ in 2009 (Fig. 21). Norway spruce and Silver fir followed the same trend from $31.8 \%$ in 2008 to $30.1 \%$ in 2009 and from $31.8 \%$ in 2008 to $27.7 \%$ in 2009, respectively. This improvement, both at individual level and for all species can be explained by the influence of elevated precipitation in previous spring and autumn seasons (2008) and during the growing season 2009. Furthermore, as compared to previous years, in the 2009 vegetation season, the excessive hot weather had a low frequency and occurred for very short periods of time. The influence upon crown condition of trees was not significant.

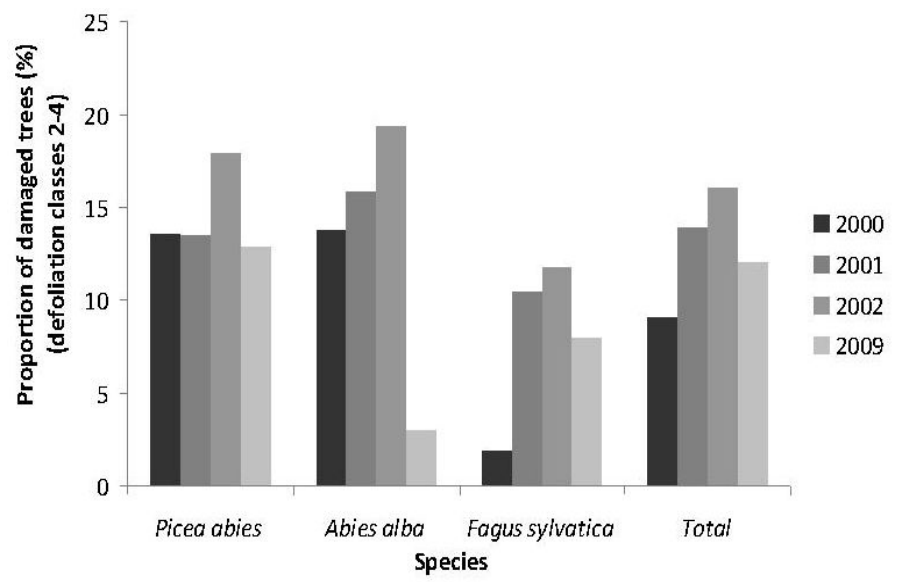

Fig. 20 - Proportion of damaged trees (group of defoliation classes 2-4) for all species during the period 2000-2002 and 2009 - Retezat NP.

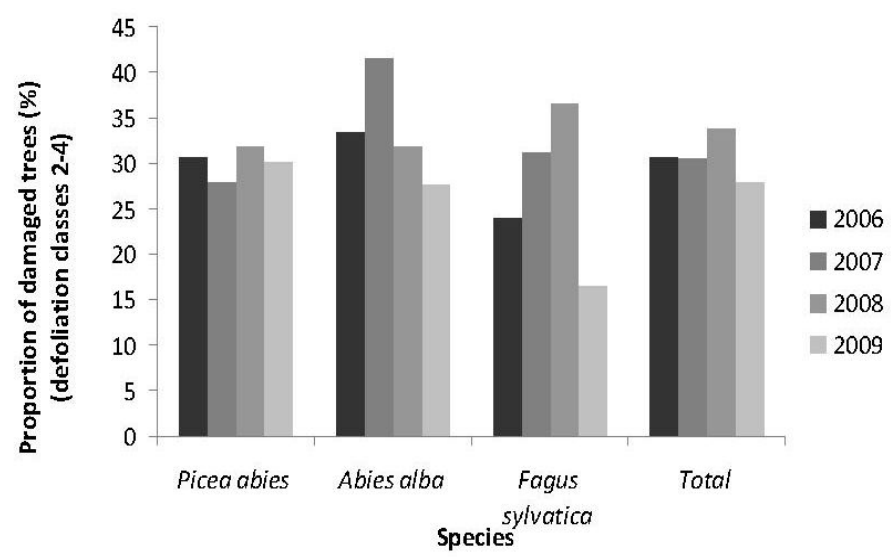

Fig. 21 - Proportion of damaged trees (group of defoliation classes 2-4) for all species during the period 2006-2009 -Bucegi NP. 


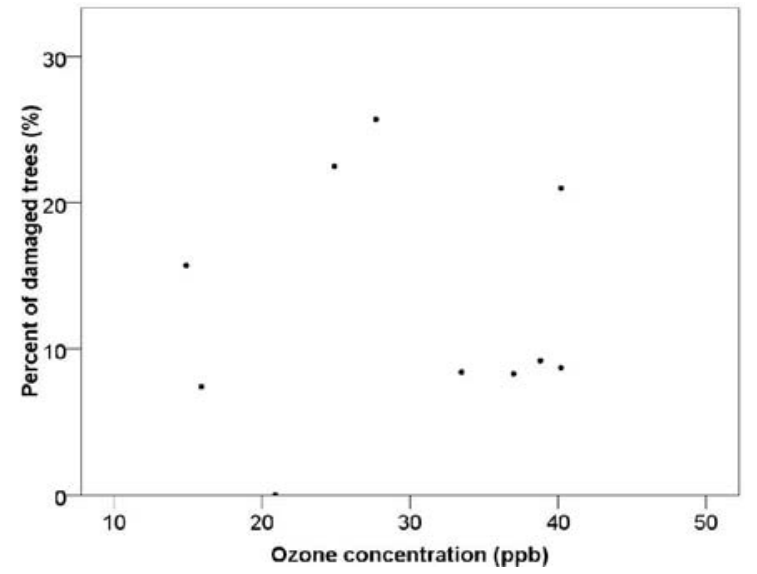

Fig. 22 - The influence of ozone concentrations on percentage of damaged trees (defoliation classes 2 - 4 - Retezat LTER Site). $\mathrm{R}^{2}$ for linear relationship was 0.002 indicating no significant effects of ambient ozone on defoliation.

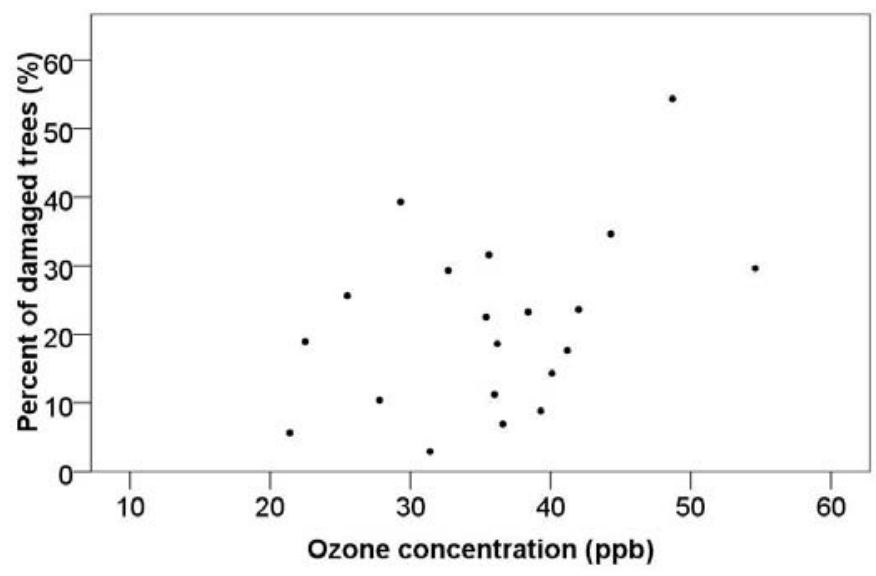

Fig. 23 - The influence of ozone concentrations on percentage of damaged trees (defoliation classes 2 - 4 - Bucegi-Piatra Craiului LTER Site). $\mathrm{R}^{2}$ for linear relationship was 0.125 indicating no significant effects of ambient ozone on defoliation.
The ambient ozone (described as seasonal mean concentrations among locations) had no significant influence on forest health status (percent of trees with crown defoliation above 25\%) in Retezat and Bucegi Mts (Fig. 22 and Fig. 23). In addition, in Bucegi mountains forests, ozone concentration had no effect on annual volume growth losses (due to action of different stress factors) (Fig. 24). In fact, ozone concentrations in Romanian Carpathians were rather low and below the levels considered to be toxic for Norway spruce and European beech, especially in Retezat (Bytnerowicz et al. 2005) and Bucegi-Piatra Craiului Mts.

The dynamics of annual average ring width was analyzed both for healthy trees (defoliation classes 0-1) and damaged trees (defoliation classes 2-3) during the entire life of selected trees. The results were relevant for most of the forest stands studied in these two LTER Sites, showing downward increment tendency of damaged trees compared with healthy trees (Bytnerowicz et al. 2005). This comparative dynamics of annual mean radial

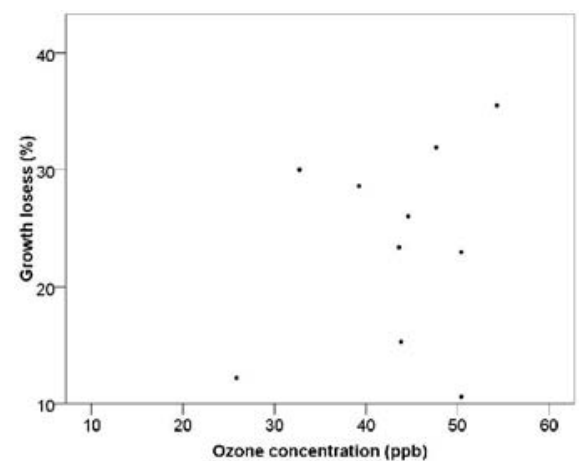

Fig. 24 - The influence of ozone concentration on growth losses (Bucegi NP). $\mathrm{R}^{2}$ for linear relationship was 0.047 indicating no significant effects of ambient ozone on growth losses. increment shows the reference moments for sive drought, air pollution, pathogens and the beginning of declining process of trees which at present are damaged, as an effect of some negative events in the past, like excespests actions, human activities, etc. (Fig. 25 and Fig. 26).

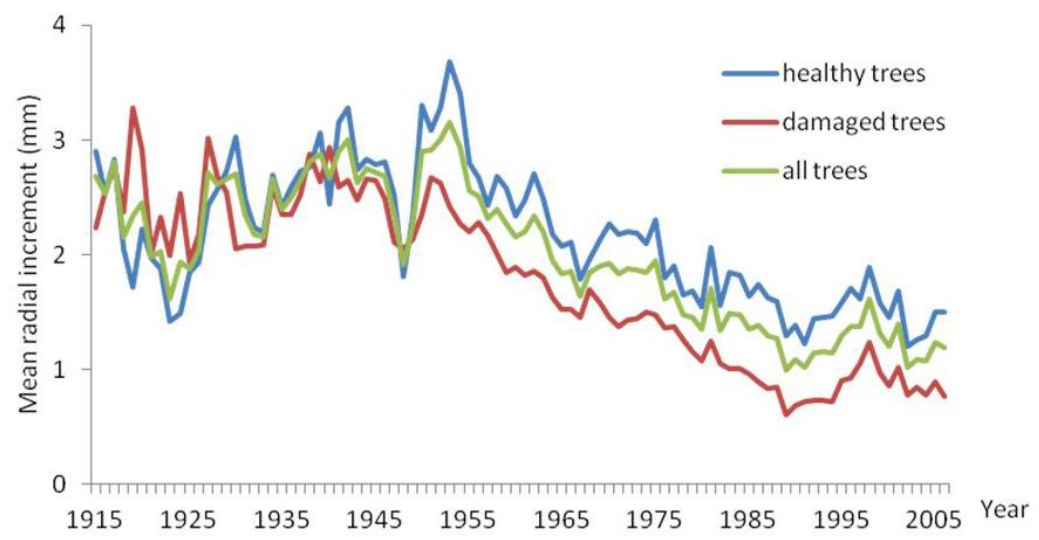

Fig. 25 - Dynamics of annual mean radial increment of Picea abies per defoliation group classes (0-1 and 2-3) in Podul cu Flori permanent plot (Bucegi NP).

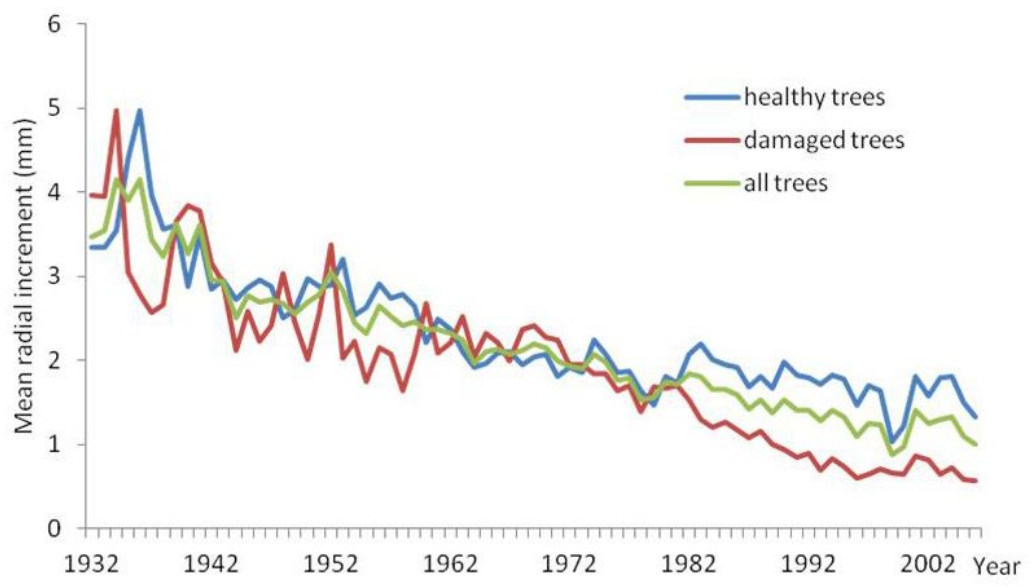

Fig. 26 - Dynamics of annual mean radial increment of Fagus sylvatica per defoliation classes (0-1 and 2-3) in Dichiu permanent plot (Bucegi NP). 
Tab. 6 - Vegetation community types in Bucegi NP*. (*): in Piatra Craiului National Park there is not yet a complete dataset on biodiversity, since the first assessment was carried out in aestival period of the year 2009.

\begin{tabular}{|c|c|c|}
\hline $\mathbf{N}$ & Plant community & $\begin{array}{c}\text { LTERP } \\
\text { (number of vegetal species) }\end{array}$ \\
\hline 1 & $\begin{array}{l}\text { Piceetum oxalidosum } \\
\text { Chirita, } 1953\end{array}$ & $\begin{array}{l}\text { Salvamont Bran (42), Timen- } \\
\text { Grofi (57), Valea cu brazi (45), } \\
\text { Brandusi (48) }\end{array}$ \\
\hline 2 & $\begin{array}{l}\text { Fagetum abietosum } \\
\text { Domin, } 1933\end{array}$ & Observator Urs (37) \\
\hline 3 & $\begin{array}{l}\text { Allio ursinae - Fagetum } \\
\text { sylvaticae nov. ass. }\end{array}$ & Poiana Stanii (45) \\
\hline 4 & $\begin{array}{l}\text { Pulmonario rubrae - } \\
\text { Fagetum sylvaticae }\end{array}$ & Dichiu (54) \\
\hline 5 & $\begin{array}{l}\text { Fagetum sylvaticae - Ade- } \\
\text { nostyletum alliariae nov.ass. }\end{array}$ & Cariera Lespezi (46) \\
\hline 6 & $\begin{array}{l}\text { Piceetum myrtillosum } \\
\text { Chirita, } 1953\end{array}$ & $\begin{array}{l}\text { Podul cu flori (49), Batrana } \\
\text { (54) }\end{array}$ \\
\hline
\end{tabular}

Tab. 7 - Vegetation community types in Retezat NP.

\begin{tabular}{|c|c|c|}
\hline $\mathbf{N}$ & Plant community & $\begin{array}{l}\text { LTERP (number of ve- } \\
\text { getal species) }\end{array}$ \\
\hline 1 & $\begin{array}{l}\text { Luzulo - fagetum (Beldie 51) } \\
\text { Mor. et al. } 68 \text { myrtilletosum Soİ } \\
62\end{array}$ & $\begin{array}{l}\text { Campusel (11), Baleia Urs } \\
\text { (20), Gura Zlata (6), }\end{array}$ \\
\hline 2 & $\begin{array}{l}\text { Hieracio (transsilvanico) - } \\
\text { Picetum Pawl. Et Br. B1.39,em. } \\
\text { Bohr } 75 \text {, oxalidentosum }\end{array}$ & $\begin{array}{l}\text { Judele (36), Baleia So- } \\
\text { hodol (12) }\end{array}$ \\
\hline 3 & $\begin{array}{l}\text { Piceto - Fagetum carpaticum } \\
\text { Klika } 27 \text { (Dacicum Beldie 67, tip } \\
\text { Luzula - Calamagrostis) }\end{array}$ & OGA (21), Riusor (18) \\
\hline 4 & $\begin{array}{l}\text { Pulmonario (rubrae) - Abieti - } \\
\text { Fagetum SoÏ } 64\end{array}$ & Rotunda (25) \\
\hline 5 & $\begin{array}{l}\text { Phyllitidi - Fagetum Vida } 1963 \\
\text { (Acereto - Fraxinetum Pauca 41) }\end{array}$ & Baleia Stana (21) \\
\hline 6 & $\begin{array}{l}\text { Fagetum carpatica Klika } 27, \\
\text { oxalidentosum Vida } 59\end{array}$ & Campusel Neagu (32) \\
\hline
\end{tabular}

\section{Biodiversity}

Retezat and Bucegi-Piatra Craiului Mts are characterized by rich and varied vegetation, protected under special regulations in order to preserve rare and endemic species. Both sites are dominated by forests and alpine meadows, harmoniously embedded in the steep and rocky terrain and home of several glacial lakes and water courses. Across the entire area over 1100 plant species have been identified, of which many are endemic (Nyarady 1958, Beldie 1967).

The research on forest vegetation across each LTER site was carried out based on a list of species organized by layers (A-trees, B-shrubs, C-herbaceous plants, D-mosses). The coverage ratio was assessed for each layer using the Braun-Blanquet method, allowing the identification of 6 representative plant communities, in each research site (Tab. 6 and Tab. 7).

European beech (Fagus sylvatica) and Nor-

way spruce (Picea abies) are the main tree species in the studied sites, along with silver fir (Abies alba), which seldom is found. Maple (Acer pseudoplatanus), Scots pine (Pinus sylvestris), birch (Betula pendula) and rowan (Sorbus aucuparia) are secondary species.

The identified plant communities are relatively diverse, ranging from pure stands of Norway spruce or European beech to mixed stands of European beech and Norway spruce or silver fir and European beech, and having in their composition other resinous species (larch, pine) and broadleaf species (mountain maple, birch, mountain ash, etc.). The number of plant species varies between 37 and 57 in Bucegi (Tab. 6) and between 11 and 36 in Retezat (Tab. 7). At least in the Retezat LTER site, by comparing the biodiversity parameters assessed in the years 2000 and 2009 , there is no confirmation regarding

Tab. 8 - Dendrometric diversity of trees for representative stand types in Retezat NP.

\begin{tabular}{ccccc}
\hline \multirow{2}{*}{ Stand type } & \multicolumn{2}{c}{ DBH } & \multicolumn{2}{c}{ Height } \\
\cline { 2 - 5 } & $\begin{array}{c}\text { Average } \\
(\mathbf{c m})\end{array}$ & $\begin{array}{c}\text { Variation } \\
\text { coefficient }\end{array}$ & $\begin{array}{c}\text { Average } \\
(\mathbf{m})\end{array}$ & $\begin{array}{c}\text { Variation } \\
\text { coefficient (\%) }\end{array}$ \\
\hline Spruce-stand & $24-33$ & $48-88$ & $19-26$ & $10-26$ \\
Beech-stand & $25-29$ & $65-161$ & $17-27$ & $10-35$ \\
Mixed-stand & $19-42$ & $47-149$ & $20-30$ & $23-41$ \\
\hline
\end{tabular}

Tab. 9 - Dendrometric diversity of trees for representative stand types in Bucegi NP.

\begin{tabular}{ccccc}
\hline \multirow{2}{*}{ Stand type } & \multicolumn{2}{c}{ DBH } & \multicolumn{2}{c}{ Height } \\
\cline { 2 - 5 } & $\begin{array}{c}\text { Average } \\
\text { (cm) }\end{array}$ & $\begin{array}{c}\text { Variation } \\
\text { coefficient (\%) }\end{array}$ & $\begin{array}{c}\text { Average } \\
\mathbf{( m )}\end{array}$ & $\begin{array}{c}\text { Variation } \\
\text { coefficient (\%) }\end{array}$ \\
\hline Spruce-stand & $17-52$ & $35-48$ & $13-30$ & $17-21$ \\
Beech-stand & $27-32$ & $56-74$ & $20-23$ & $23-51$ \\
Mixed-stand & $22-30$ & $35-73$ & 25 & $18-33$ \\
\hline
\end{tabular}

rapid environmental modifications, and furthermore no significant reduction of biodiversity.

In most of the pure or mixed European beech stands (European beech and Norway spruce, European beech and silver fir) there is evidence of superior richness of species compared to the Norway spruce pure stands. In a similar manner, dendrometric parameters of trees fluctuate in relation to stand structure and site type, demonstrating higher diversity in European beech and mixed stands than in Norway spruce pure stands (Tab. 8 and Tab. 9).

Diameter diversity, diameter-height relation and age structure patterns reveal spatial variability and the value of ecological potential. Spatial variability is linked with environmental influences, especially with effects of disturbance, including pollution and climate change stressors, biotic interactions and substrate fertility. As a limited conclusion to the extent of the research plots, all the vegetation biodiversity components of the forest ecosystems are specific for the stand type's structures and climatic conditions, and concerning the air pollution stressor, it seems there are no significant consequences on ecosystems' biodiversity component.

\section{Conclusions}

1. In general, the air quality in the Retezat and Bucegi - Piatra-Craiului Mts was relative good during the study period.

2. The ambient ozone concentrations were situated under critical limits. There was no significant influence of ozone levels on tree crown condition and annual volume growth losses assessed on trees with high crown defoliation (damaged trees). The spatial and temporal $\mathrm{O}_{3}$ distribution in the area was stable. Generally location had a 
significant influence on ozone concentrations whereas the effect of the exposure period during the growing season was evident only in some cases.

3. Depositions estimated in the soil solution (collected by lysimetric plates) were generally higher than in the open field because of the accumulation of the ions in the soil layers. Along the soil profile the fluxes of the main pollutant ions decreased, while others (e.g., $\mathrm{Ca}^{+2}$ ) were highly influenced by the soil substrate and soil type. The study validated the use of a long-term integrated monitoring program for the evaluation of the impact of pollutants on forests and assessed the role of the forests in buffering the acidity of the rain.

4. Forest health status (crown condition) was better in Retezat than in Bucegi or Bucegi Piatra Craiului region, where air pollution and anthropogenic influence have had a major effect in the close past. These forest ecosystems can be considered as moderately affected. Abies alba and Picea abies were more affected than Fagus sylvatica, which was the healthiest species at national level.

5. Variation of annual mean radial increment per defoliation group class (0-1 and 2-3) offered very good information on major negative events in the past, like very strong drought, air pollution, windfalls, human activities and inappropriate forest management.

6. There was no evidence of rapid environmental modifications, and furthermore no significant reduction of biodiversity. In addition, all the vegetation biodiversity components of the forest ecosystems were specific to the types of stand structures and local climate conditions, and concerning the air pollution stressor, it seems there were no quantifiable consequences on ecosystems' diversity.

\section{Acknowledgements}

The long-term monitoring researches in Retezat and Bucegi - Piatra-Craiului LTER Sites were financed by USDA - Forest Service International Programs (2000-2002) then by the Excellence Program of the Romanian Authority for Research (2005-2008). Researches were conducted under a close and fruitful collaboration between ICAS, USDA - Forest Service, "Transilvania" University, University of Bucharest and Nation- al Forest Administration (Romsilva). Since 2009, these long-term monitoring researches continue with the support of Romanian Authority for Research under the GEDEOFOR Program and the LIFE+ Program (EnvEurope project), cofinanced by the European Commission and Romsilva. The scientific activities and main results on long term monitoring research in Retezat and Bucegi-Piatra Craiului LTER sites were presented at the 24th IUFRO Conference for Specialists in Air Pollution and Climate Change Effects on Forest Ecosystems "Adaptation of Forest Ecosystems to Air Pollution and Climate Change" in Antalya and the manuscript was written within the COST Action FP0903 Climate Change and Forest Mitigation and Adaptation in a Polluted Environment.

\section{References}

Badea O (1998). Fundamente dendrometrice si auxologice pentru monitoringul forestier. Ph.D. thesis, "Stefan cel Mare" University, Suceava, Romania, pp. 177.

Badea O, Patrascoiu N, Geambasu N, Barbu I, Bolea V (1998). Forest condition monitoring in Romania. Office National de Forets, Departement des Recherches Techniques, Bucharest, Romania, pp. 62.

Badea O, Popescu F, Bytnerowicz A, Musselman R, Cenusa R, Barbu I, Ganz V, Tanase M (2002). Long term effects of air pollution on selected forest ecosystems in the Carpathian Mountains (Retezat National Park, Romania). In: Proceedings of the NATO Advanced Workshop on "Effects of air pollution on forest health and biodiversity in forests of the Carpathian Mountains" (Szaro RC ed). Stara Lesna (Slovakia), 22-26 May 2002, IOS Press.

Badea O (2008). Manual on methodology for long term monitoring of forest ecosystems status under air pollution and climate change influences (in Romanian). Ed. Silvica, Bucharest, Romania, pp. 100 .

Beldie A (1967). Flora si vegetatia muntilor Bucegi. Ed. Academiei, Bucharest, Romania, pp. 578.

Bredemeyer M (1988). Forest canopy transformation of atmospheric deposition. Water, Air and Soil Pollution 40: 121-138.

Brumme R, Leimcke U, Matzner E (1992). Interception and uptake of $\mathrm{NH}_{4}$ and $\mathrm{NO}_{3}$ from wet deposition by above-ground parts of young beech. Plant and soil 142: 273-279. - doi: 10.1007/ BF00010972

Barbu I, Iacoban C (2008). Quantitative and qualitative sampling and analysis of pollutant ions fluxes (atmospheric deposition) in the forest ecosystems within the long term research network (LTRN). In: "Manual on methodology for long term monitoring of forest ecosystems status under air pollution and climate change influences" (in Romanian). Ed. Silvica, Bucharest, Romania, pp. 55-62.

Bytnerowicz A, Arbaugh MJ, Schiilling SL (1998). Air pollution and climate change effects on forest ecosystems. In: Proceedings of the International Symposium of the USDA Forest Service. General technical report PSW-GTR-166, USDA Forest Service, Pacific Southwest Research Station, Berkeley, CA, USA.

Bytnerowicz A, Badea O, Popescu F, Musselman R, Tanase M, Barbu I, Fraczek W, Geambasu N, Surdu A, Danescu F, Postelnicu D, Cenusa R, Vasile C (2005). Air pollution, precipitation chemistry and forest health in the Retezat Mountains, Southern Carpathians, Romania. Environmental Pollution 137: 546-567. - doi: 10.1016/ j.envol.2005.01.040

Bytnerowicz A, Badea O, Musselmann R, Neagu $\mathrm{S}$ (2008). Assessment of ozone $\left(\mathrm{O}_{3}\right)$ and other phytotoxic agents $\left(\mathrm{NH}_{3}, \mathrm{NO}_{2}\right.$ and $\left.\mathrm{SO}_{2}\right)$ in the long term research network. In: "Manual on methodology for long term monitoring of forest ecosystems status under air pollution and climate change influences" (in Romanian). Ed. Silvica, Bucharest, Romania, pp. 75-82.

Dise NB, Matzner E, Gundersen P (1998). Synthesis of nitrogen pools and fluxes from European forest ecosystems. Water, Air and Soil Pollution 105: 143-154.

Grodzinska K, Godzik B, Fraczek W, Badea O, Oszlanyi J, Postelnicu D, Shparyk Y (2004). Vegetation of the selected forest stands and land use in the Carpathian Mountains. Environ. Pollut. 130: 17-32. - doi: 10.1016/j.envpol.2003.10.031 Lindberg SE, Lovett GM (1992). Deposition and forest canopy interactions of airborne sulphur: results from integrated forest study. Atmospheric Environment 26: 1477-1492.

Nyarady EI (1958). Flora si vegetatia munèilor (Retezat ed). Academiei Romane, Bucharest, Romania, pp. 195.

UN/ECE, ICP-Forests (2004). Manual on methods and criteria for harmonized sampling, assessment, monitoring and analysis of the effects of air pollution on forests. Hamburg, pp. 173.

Vadineanu A, Badea O, Gheorghe IF, Neagu S, Postelnicu D (2008). New insights on the dynamics of the forest vegetation from the Romanian Carpathian Mountains. Ekologia, Bratislava 27: 269-287. 